Article

\title{
Chromium(VI) Removal by Polyvinyl Chloride (PVC)/Aliquat-336 Polymeric Inclusion Membranes in a Multiframe Flat Sheet Membrane Module
}

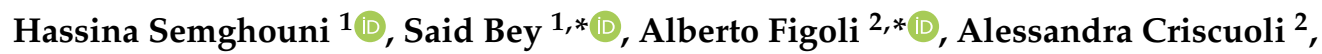 \\ Francesca Russo ${ }^{2}$, Benamor Mohamed ${ }^{1}(\mathbb{D})$ and Enrico Drioli ${ }^{2}$ (D) \\ 1 Laboratory of Membrane Processes and Techniques of Separation and Removal, Faculty of Technology, \\ Bejaia University, Bejaia 06000, Algeria \\ 2 Institute on Membrane Technology (ITM-CNR), Via P.Bucci 17/C, 87036 Rende (CS), Italy \\ * Correspondence: said.bey@univ-bejaia.dz (S.B.); a.figoli@itm.cnr.it (A.F.)
}

Received: 7 June 2019; Accepted: 22 July 2019; Published: 25 July 2019

\begin{abstract}
A new multiframe flat sheet membrane contactor module containing several flat membranes was designed and implemented. Each frame contains a chamber (central hole) in which the feed and the receiving phases are put in contact with polyvinyl chloride (PVC)/Aliquat-336 polymeric flat sheet membranes for $\mathrm{Cr}(\mathrm{VI})$ removal from aqueous solutions (feed phase). To evaluate the efficiency of the system, the experimental design methodology was used to analyze the effect of temperature $\left(\mathrm{T},{ }^{\circ} \mathrm{C}\right)$, PVC/Aliquat-336 ratio, and $\mathrm{Cr}$ (VI) concentration in the feed phase and the concentration of sodium chloride $(\mathrm{NaOH}-\mathrm{NaCl})$ in the receiving phase. Two representative mathematical models of the two responses (extraction and back-extraction) were respectively obtained. A good correlation between the experimental results and those predicted $\left(R_{S}{ }^{2}=97.77\right.$ and $\left.R_{R}{ }^{2}=97.87\right)$ was achieved, allowing the optimization of the different factors selected for each response, separately. The proposed system showed a good separation performance, leading to $\mathrm{Cr}(\mathrm{VI})$ extractions up to $93 \%$ when working at the optimized operating conditions.
\end{abstract}

Keywords: multiframe membrane module; PVC; Aliquat-336; Cr(VI); experimental design

\section{Introduction}

Membrane contactors are widely used for separating and recovering pollutant species, especially in trace amounts [1-3]. In recent years, polymer inclusion membranes (PIMs) have attracted a lot of interest in a wide range of separation process, and they have grown in popularity, especially for small organic compounds [4] and metal ion separation from aqueous solutions [5,6], such as chromium [7], aluminum [8], $\mathrm{Au}$ (III) [9], copper (II) [10], zinc [11], cadmium [12], cobalt [13], and lead [14]. Moreover, PIMs have reached the agricultural sector for the extraction of pesticides that, due to their toxicity, pose a great risk to human health [15]. The first use of PIMs has been suggested more than 50 years ago and considered both liquid and dense membranes [16-18]. In the literature, in fact, scientists classified them in the category of liquid membranes while others hesitate between liquid and solid. PIMs are essentially composed of a polymer dissolved in a suitable solvent; the carrier (liquid phase) is added and physically trapped in the membrane matrix providing significant stability compared to other liquid membranes [19]. Most PIMs contain a plasticizer or modifier for an appropriate separation or specific application. These membranes became attractive in separation processes and presented an alternative technique for solvent extraction. They are considered environmentally friendly and economic because of the simple procedure for their preparation and the very low amount of solvent and extractant used [18,20-24]. In general, polyvinyl chloride (PVC) and cellulose triacetate (CTA) were used as basic 
materials [25-30]. The removal of chromium(VI) from industrial effluents and contaminated waters is very important because of its high toxicity and impact on both human health and the environment. Chromium (VI) extraction has been widely investigated using PIM, and the most used devices have been double compartment or microdevices $[18,25,31,32]$. All systems investigated by researchers have been double cell systems or microsystem channels. Pandey et al. [33] reported the extraction of $\mathrm{Cr}(\mathrm{VI})$ by polymeric inclusion membranes based on CTA and Aliquat-336; a high permeability combined with stability, comparable to supported liquid membrane, was observed. Similar results were obtained by Kozlowski et al. [34] in their comparative study between supported liquid membranes SLM and PIMs using CTA and Aliquat-336 as carriers. Kebiche-Senhadji et al. [35] reported a high stability of PIMs based on CTA/Aliquat-336 for $\mathrm{Cr}(\mathrm{VI})$ transport in a double cell system, with a constant permeability coefficient after 12 cycles of use. A comprehensive review on PIM applications and the systems used is reported by Almeida [18].

In the present work, for the first time, a multiframe flat sheet membrane module was designed and used for the extraction of $\mathrm{Cr}(\mathrm{VI})$ containing a series of chambers alternating feed and receiving phases. With respect to the systems reported in the literature, the multiframe module is an example of a compact design that could be adopted to scale up the technique. To optimize the efficiency of the system, design of experiment (DOE) has been used to evaluate all parameters of the system and their interactions. In particular, for the first time, DOE was used for investigating parameters of polymeric inclusion membranes in a multiframe plates module. This methodology allows to reduce the number of experiments, which avoids product waste and loss of time [36-38].

\section{Materials and Methods}

\subsection{Experimental Apparatus}

In this study, a new membrane module was used. The module, called a multiframe flat sheet membrane contactor, consisted of eight flat Teflon frames with dimension of $7 \times 7 \mathrm{~cm}$. Each frame had a $29 \mathrm{~mm}$ central hole, $\approx 1 \mathrm{~cm}$ thick, corresponding to $\approx 6.6 \mathrm{~cm}^{2}$ membrane area as a chamber where the solutions flow, and lateral, small $3 \mathrm{~mm}$ holes for feeding and exiting solutions. No spacers were used in the channels. The clamping of frames was ensured by four threaded rods. Between two frames, a flat sheet membrane sandwiched between two plastics gaskets separated the two phases: feed (F) phase and receiving $(\mathrm{R})$ phase. The system was fed in counter-current mode and the phases were recirculated at a flow rate of $0.3 \mathrm{~mL} / \mathrm{s}$ by using a peristaltic pump, flowing from the outlet of one frame to the inlet of the following frame (Figure 1). The operating temperatures were controlled by thermostatic bath. Table 1 summarizes the experimental conditions of all the experiments.

(a)

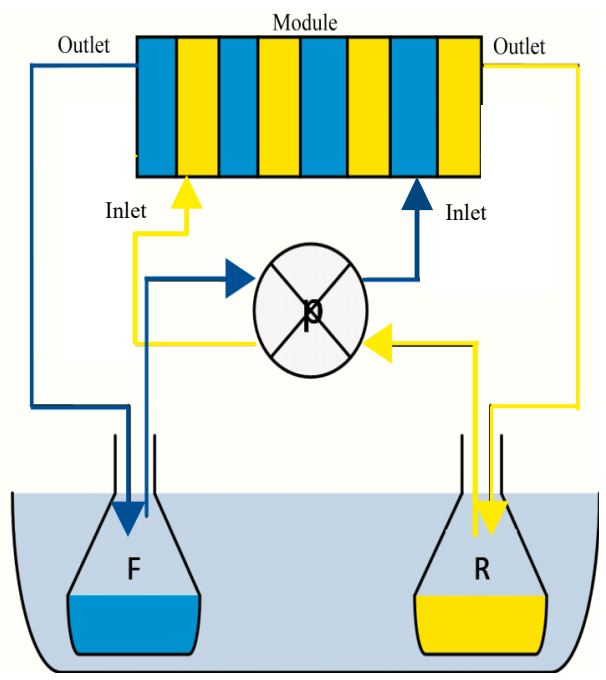

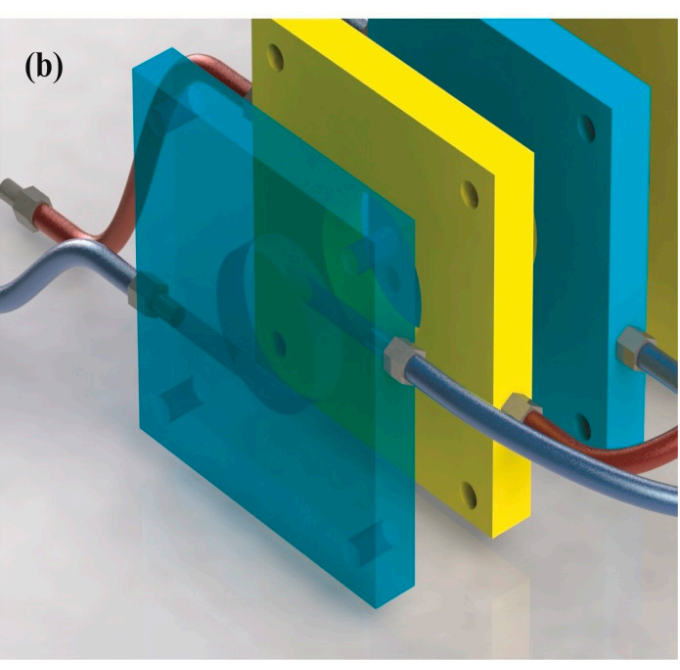

Figure 1. Simplified scheme of the experimental set up (a) and frames (b). 
Table 1. Experimental conditions.

\begin{tabular}{cccccccc}
\hline $\begin{array}{c}\text { Number } \\
\text { of Frames }\end{array}$ & $\begin{array}{c}\text { Number of } \\
\text { Membranes }\end{array}$ & $\begin{array}{c}\text { Type of } \\
\text { Membranes }\end{array}$ & $\begin{array}{c}\text { Feed Phase } \\
\text { Composition }\end{array}$ & $\begin{array}{c}\text { Receiving } \\
\text { Phase } \\
\text { Composition }\end{array}$ & $\begin{array}{c}\Delta \mathbf{P} \\
(\mathbf{b a r})\end{array}$ & $\begin{array}{c}\text { Temperature } \\
\left({ }^{\circ} \mathbf{C}\right)\end{array}$ & $\begin{array}{c}\text { Flow } \\
(\mathbf{m L} / \mathbf{s})\end{array}$ \\
\hline 8 & 7 & $\begin{array}{c}\text { Polyvinyl chloride } \\
(\mathrm{PVC}) / \text { Aliquat-336 }\end{array}$ & $\mathrm{Cr}(\mathrm{VI})$ & $\mathrm{NaOH}-\mathrm{NaCl}$ & 0 & $20,30,50$ & 0.3 \\
\hline
\end{tabular}

\subsection{Reagents}

PVC (Solvin, BASF, Hannover, Germany, $\mathrm{M}=233,000 \mathrm{~g} / \mathrm{mol}, \mathrm{d}=1.2 \mathrm{~kg} / \mathrm{L}$ ) was used as base polymer, tetra hydrofurane THF (Biochem Chemopharma, Cosne sur Loire, France, $\mathrm{d}=0.886-0.889 \mathrm{~kg} / \mathrm{L}$ ) was used as a solvent for PVC, and tricaprylmethylammonium (Aliquat-336) (Sigma Aldrich, Darmastadt, Germany, $\mathrm{M}=404.17 \mathrm{~g} / \mathrm{mol}, \mathrm{d}=0.884 \mathrm{~kg} / \mathrm{L}$, assay $=99$ ) was used as carrier.

Potassium dichromate $\left(\mathrm{K}_{2} \mathrm{Cr}_{2} \mathrm{O}_{7}\right)$ (Prolab, Fontenaysous-Bois, France, $\mathrm{M}=294.18 \mathrm{~g} / \mathrm{mol}$, assay $=98 \%$ ) was used for preparing the aqueous feed solutions of different concentrations. $\mathrm{NaOH}$ (Biochem Chemopharma, Montreal, QC, Canada, assay $=97 \%$ ) and $\mathrm{NaCl}$ (Labosi, Elancourt, France, $\mathrm{M}=85.44 \mathrm{~g} / \mathrm{mol}$, assay $=99 \%)$ were used to prepare $\mathrm{NaOH}-\mathrm{NaCl}$ solutions $(0.1-1 \mathrm{M})$ and $(0.1-2 \mathrm{M})$ as a receiving phase.

\subsection{Membrane Preparation and Testing}

The inclusion polymer membranes were prepared by the solvent evaporation technique. An amount of the polymer $(0.4 \mathrm{~g})$ was dissolved in the THF. After complete dissolution, a homogeneous solution was obtained, and Aliquat-336 was added at different ratios (1/0.5, 1/0.75, and 1/1). Homogeneous solutions were kept under low agitation for $1 \mathrm{~h}$ to eliminate air bubbles (degassing time). Finally, the polymeric solutions were poured into a $9 \mathrm{~cm}$ diameter Petri dish for solvent evaporation for $24 \mathrm{~h}$. In order to get a smooth surface and dense membrane without any defects, the solvent was evaporated slowly by covering the Petri dish with a lid. The produced membranes were washed with distilled water for further characterization. For this purpose, several techniques were used, such as scanning electron microscopy (SEM) (Zeiss- EVO-Ma10, Oerzen, Germany), infrared spectroscopy (Nicolet iN10 710, Waltham, USA), and contact angle (CAM 100, Nordtest Srl, Serravalle Scrivia, Italy). In addition to the above characterization techniques, to better understand the membrane properties, it was important to carry out both thermal and mechanical tests. However, in this preliminary investigation, no thermal analysis was made, considering that the produced membranes were used up to $50^{\circ} \mathrm{C}$, in order to avoid any evaporation of aqueous solutions and concentrations of species, as well as loss of Aliquat-336. Also, no mechanical tests were carried out due to the small size of the membrane samples sandwiched between frames and to the low (atmospheric) operating pressures. The produced membranes were sandwiched between each two frames making a total of seven (07) membranes for eight (08) frames. After module preparation, the feed and receiving phases were fed at $0.3 \mathrm{~mL} / \mathrm{s}$ and the desired temperature in a counter-current mode by a peristaltic pump, filling the chambers inside the frames. Samples were taken from the two phases to analyze the $\mathrm{Cr}(\mathrm{VI})$ content.

\subsection{Application of Design of Experiment (DOE)}

Chromium (VI) extraction by PIMs based on PVC/Aliquat-336 was carried out using the design of experiment methodology (DOE) with MINITAB 17. The aim of this study was to evaluate the effects of the different parameters as well as the possible interactions that may exist among these operating parameters. For that, a two-level $2^{n}$ full factorial design of experiments was first constructed to visualize the effects of the factors and their interactions on the extraction and back-extraction efficiency of $\mathrm{Cr}(\mathrm{VI})$, where $\mathrm{n}=$ number of factors under verification (here $\mathrm{n}=3$ ). Thus, the total number of experiments required to study each response was eight (8). Two responses were chosen: the extraction efficiency of $\mathrm{Cr}(\mathrm{VI})$ in the source (feed) phase and the back-extraction efficiency of $\mathrm{Cr}(\mathrm{VI})$ in the receiving phase. Tables 2 and 3 show the selected range for feed and permeate phases factors, respectively. The chosen 
parameters are the most investigated and influential for extraction and back-extraction of $\mathrm{Cr}(\mathrm{VI})$ in double-cell systems. Their maximum and minimum level were chosen from what is reported in the literature $[33,35,39]$.

Table 2. Feed phase factors and fields of study.

\begin{tabular}{cccc}
\hline Factor & Names & Low Level & High Level \\
\hline$[\mathrm{Cr}(\mathrm{VI})](\mathrm{ppm})$ & $\mathrm{A}$ & 10 & 50 \\
Temperature $\left({ }^{\circ} \mathrm{C}\right)$ & $\mathrm{B}$ & 20 & 50 \\
[Aliquat-336] $(\%)$ & $\mathrm{C}$ & 50 & 100 \\
\hline
\end{tabular}

Table 3. Receiving phase factors and fields of study.

\begin{tabular}{cccc}
\hline Factor & Names & Low Level & High Level \\
\hline Temperature $\left({ }^{\circ} \mathrm{C}\right)$ & $\mathrm{A}$ & 20 & 50 \\
Aliquat-336 $(\%)$ & $\mathrm{B}$ & 50 & 100 \\
{$[\mathrm{NaCl}](\mathrm{M})$} & $\mathrm{C}$ & 1 & 2 \\
\hline
\end{tabular}

\section{Results and Discussion}

\subsection{Membrane Characterization}

\subsubsection{Scanning Electron Microscopy (SEM)}

Figure 2 shows the morphology of the membranes observed by SEM. The top and bottom images of all membranes revealed a smooth and homogeneous surface without any apparent porosity. The cross section showed a homogeneous, dense structure without any porosity. This could be explained by the solvent evaporation techniques, which usually lead to a dense membrane structure. An unexpected result was the brightness of the cross-section of the membranes probably due to the presence of Aliquat-336 in its liquid form. This is in contrast with some results in the literature where some dark regions, referring to the polymer matrix, are distinguished in the membrane matrix [40].

A

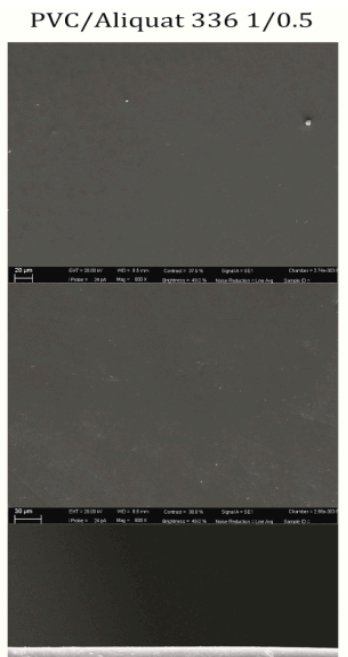

C
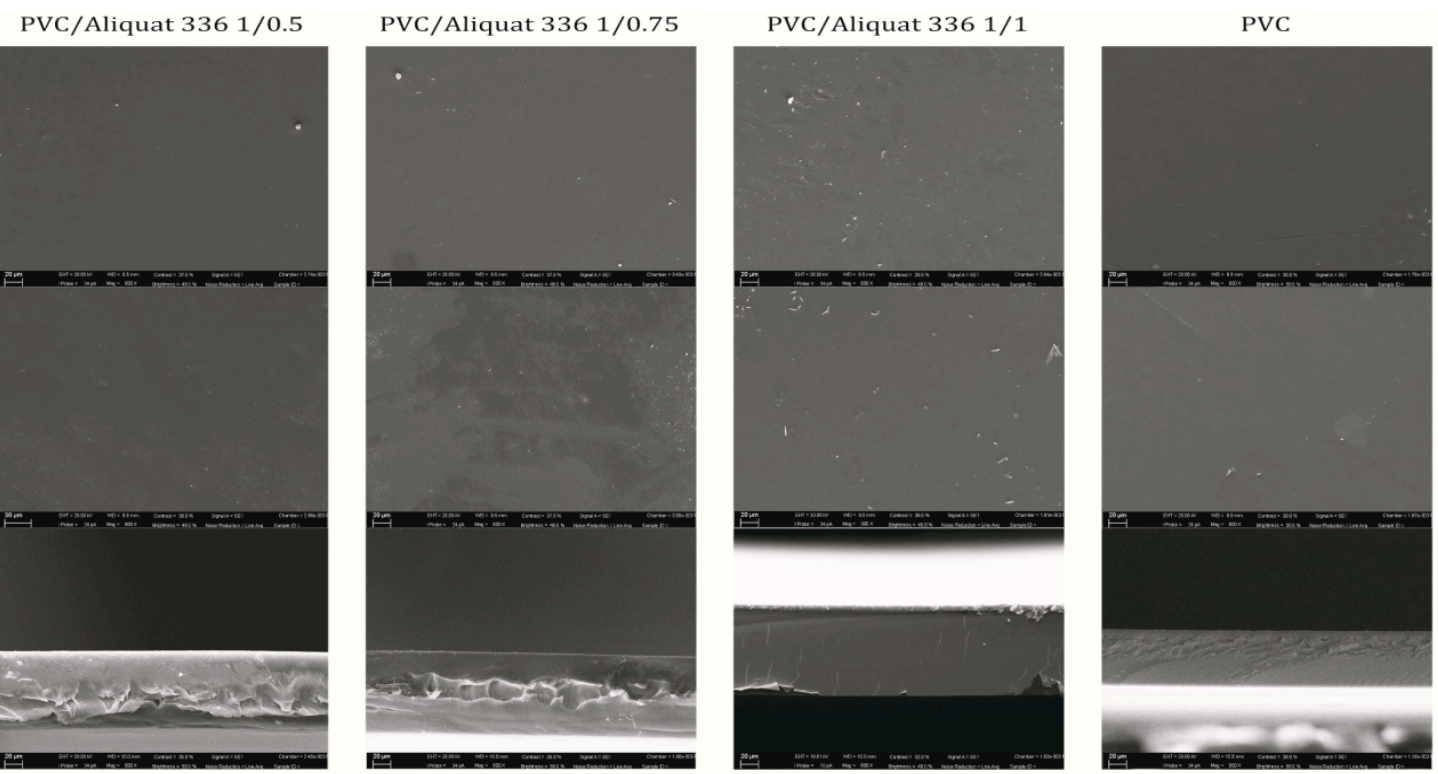

Figure 2. Scanning electron microscopy (SEM) images of the prepared membranes: (A) top surface, (B) bottom surface, and (C) cross-section. 


\subsubsection{Infrared (IR) Spectrophotometry}

In order to confirm incorporation of the Aliquat-336 carrier in the membrane matrix, an infrared analysis was performed for the virgin membrane and those containing the carrier at different amounts.

The results of the different absorption bands are presented in Figure 3.

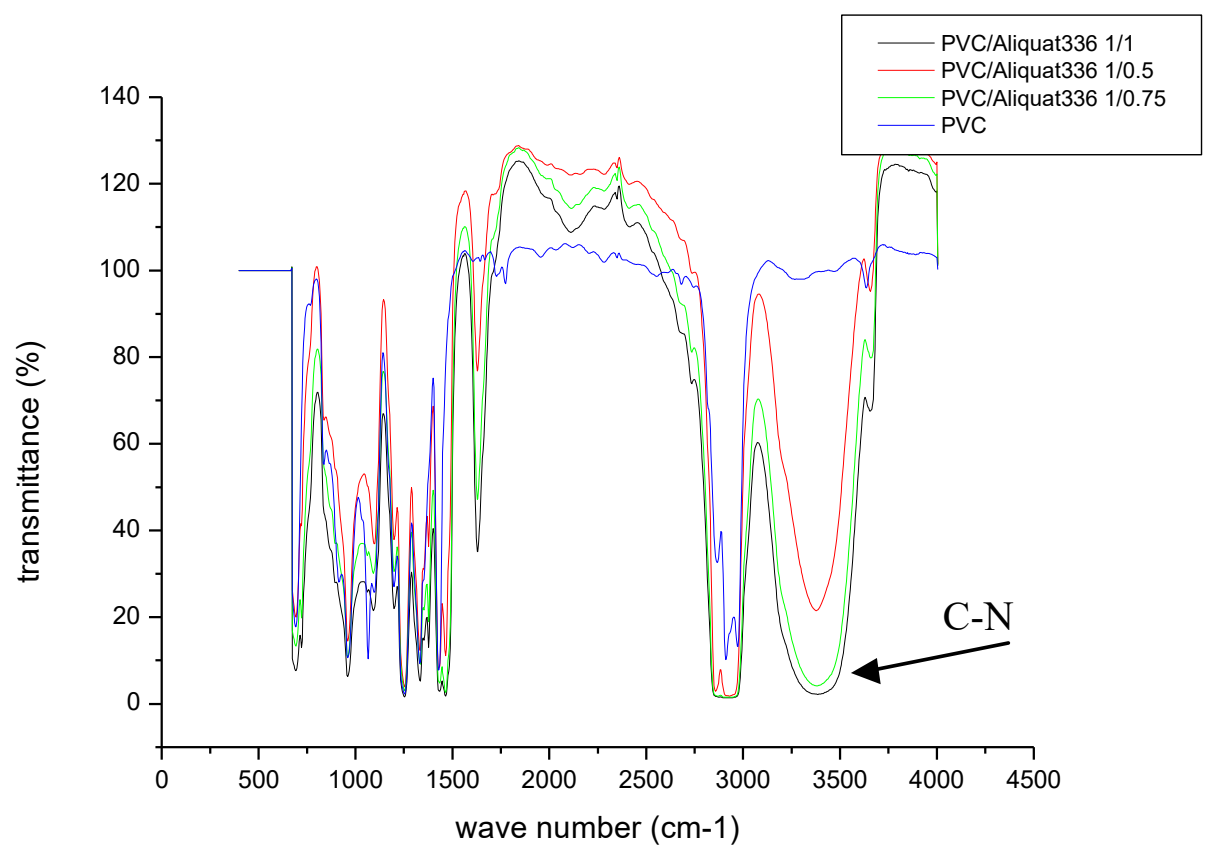

Figure 3. Infrared spectrum of the prepared membranes: PVC; PVC/Aliquat: 1/0.5; PVC/Aliquat: 1/0.75; and PVC/Aliquat: $1 / 1$.

With regard to the absorption bands of the PVC polymer, no modification in the polymer chain after the addition of the carrier was noticed. On the other hand, on the membranes containing the carrier, a new absorption band located between 3000 and $3500 \mathrm{~cm}^{-1}$ was observed. By increasing the content of Aliquat-336, the intensity of the $\mathrm{C}-\mathrm{N}$ band increased mainly at $3450 \mathrm{~cm}^{-1}$, at which no band exists in pristine PVC. This can be attributed to the $\mathrm{CN}$ group, which is a characteristic group of the Aliquat-336 carrier and, therefore, confirms its physical immobilization in the membrane matrix without the modification of the main absorption bands characteristic of the PVC polymer. Moreover, a distinct peak at $1600 \mathrm{~cm}^{-1}$ appeared, increasing in intensity at higher Aliquat-336 contents in the membrane. This was attributed to the vibration of ammonium groups of Aliquat-336. A weak band at $2250 \mathrm{~cm}^{-1}$ was also observed for the PVC/Aliquat membranes, confirming the existence of quaternary ammonium groups of Aliquat-336. Similar results were reported by Ranjbari et al. [41], confirming the formation of positive charges $\left(\mathrm{NH}_{3}{ }^{+}\right)$on the chitosan matrix. The comparison of FTIR spectra of the produced membranes showed no band displacement, assuming that Aliquat-336 is still free, and no interaction between the additive and the polymer occurs.

\subsubsection{Membrane Thickness and Contact Angle}

Figure 4 shows the results of membrane contact angle (Figure 4a) and thickness (Figure $4 \mathrm{~b}$ ) measurements with and without the addition of the Aliquat-336 carrier.

According to Figure $4 \mathrm{a}$, the contact angle of the membranes decreased by increasing the content of Aliquat-336 in the polymeric solution. This could be explained by the presence of the ammonium groups in Aliquat-336 that confer a hydrophilic character. Similar results were found by Nasser et al. [39] and Vazques et al. [42]. Figure 5 shows a photo of the water contact angle WCA measurement for the membrane at 1/0.75 PVC/Aliquat-336 ratio. The addition of Aliquat-336 did not significantly affect the thickness value, and an increase was observed only for a PVC/Aliquat-336 ratio of 1/1 (Figure 4b). 
This could be attributed to the swelling of the polymer matrix at high Aliquat-336 contents that finally affected the thickness of membranes.

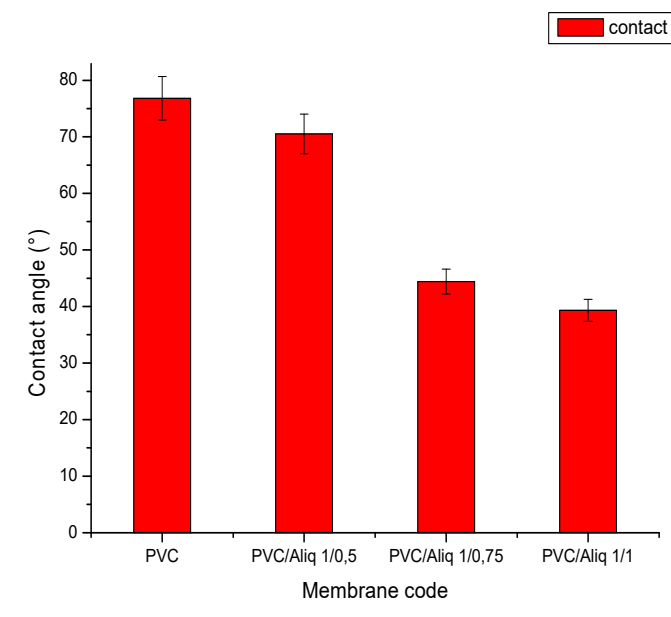

(a)

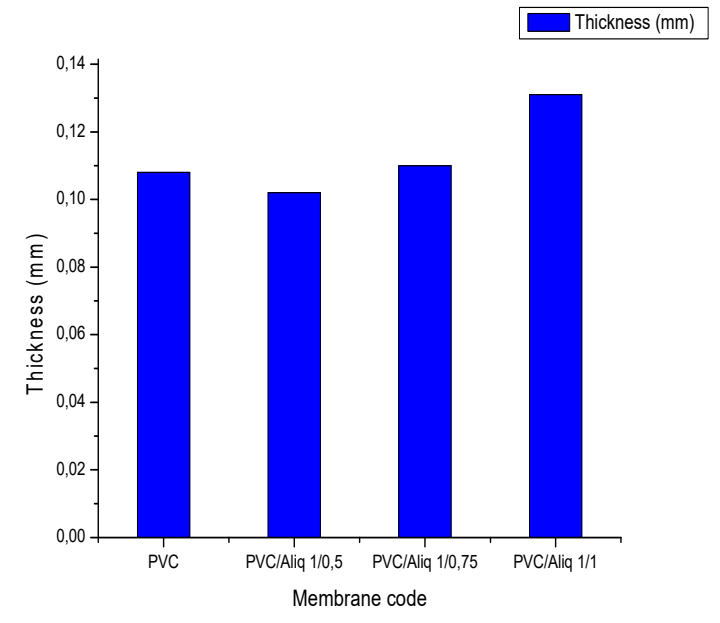

(b)

Figure 4. (a) PVC/Aliquat-336 membrane contact angle; (b) PVC/Aliquat-336 membrane thickness.

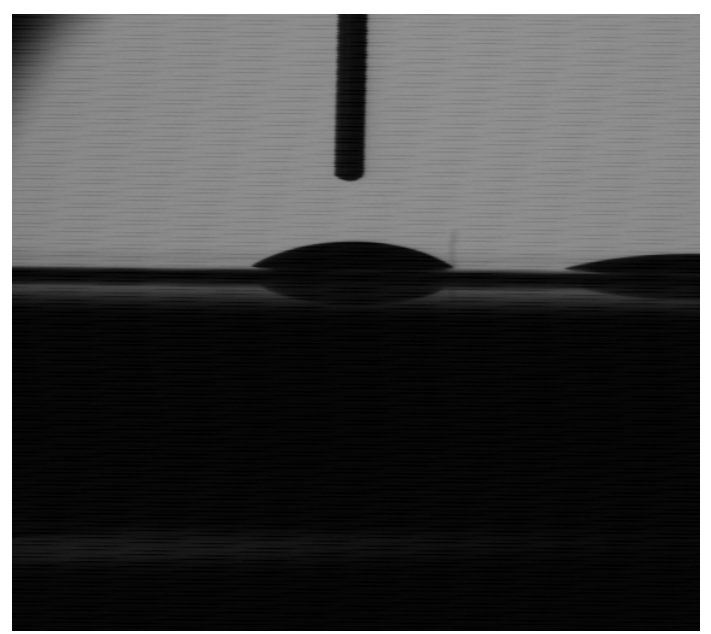

Figure 5. Photo of the water contact angle WCA measurement for the membrane at $1 / 0.75$ PVC/Aliquat-336 ratio.

\subsection{Design of Experiment (DOE)}

The different factors and their low- and high-level values were uploaded into the software MINITAB 17, which provided the following test matrix for the feed and the receiving phases (see Tables 4 and 5, respectively). In Tables 4 and 5, the experimental and the predicted yields are also listed. A total of 13 experiments were made, since 5 tests were added around the central point to minimize the error. 
Table 4. Feed phase matrix of experiments.

\begin{tabular}{cccccccc}
\hline $\begin{array}{c}\text { Run } \\
\text { Order }\end{array}$ & $\begin{array}{c}\text { Center } \\
\mathbf{P t}\end{array}$ & [Cr(VI)] & [Aliquat-336] & $\mathbf{T}$ & $\begin{array}{c}\text { Yield S } \\
\text { Experimental (\%) }\end{array}$ & $\begin{array}{c}\text { Yield S } \\
\text { Predicted (\%) }\end{array}$ & Residuals \\
\hline 1 & 0 & 0 & 0 & 0 & 88.38 & 87.03 & 1.34 \\
2 & 1 & -1 & -1 & 1 & 75.08 & 75.64 & -0.55 \\
3 & 1 & 1 & 1 & 1 & 89.02 & 89.58 & -0.55 \\
4 & 1 & -1 & -1 & -1 & 92.47 & 93.03 & -0.55 \\
5 & 0 & 0 & 0 & 0 & 87.84 & 87.03 & 0.81 \\
6 & 0 & 0 & 0 & 0 & 87.74 & 87.03 & 0.71 \\
7 & 1 & 1 & 1 & -1 & 89.62 & 89.62 & 90.18 \\
8 & 1 & -1 & 1 & 1 & 89.58 & 89.58 & 90.13 \\
9 & 0 & 0 & 0 & 0 & 87.83 & 87.03 & 0.80 \\
10 & 1 & 1 & -1 & -1 & 89.49 & 90.04 & -0.55 \\
11 & 0 & 0 & 0 & 0 & 87.79 & 87.03 & 0.76 \\
12 & 1 & 1 & -1 & 1 & 88.34 & 88.89 & -0.55 \\
13 & 1 & -1 & 1 & -1 & 78.18 & 78.73 & -0.55 \\
\hline
\end{tabular}

Table 5. Receiving phase matrix of experiments.

\begin{tabular}{cccccccc}
\hline $\begin{array}{c}\text { Run } \\
\text { Order }\end{array}$ & $\begin{array}{c}\text { Center } \\
\text { Pt }\end{array}$ & [NaCl] & [Aliquat-336] & $\mathbf{T}$ & $\begin{array}{c}\text { Yield R } \\
\text { Experimental (\%) }\end{array}$ & $\begin{array}{c}\text { Yield R } \\
\text { Predicted (\%) }\end{array}$ & Residuals \\
\hline 1 & 0 & 0 & 0 & 0 & 40.76 & 43.87 & -3.10 \\
2 & 0 & 0 & 0 & 0 & 42.66 & 4387 & -1.20 \\
3 & 1 & 1 & -1 & 1 & 50.48 & 49.60 & 0.87 \\
4 & 0 & 0 & 0 & 0 & 43.17 & 43.87 & -0.70 \\
5 & 1 & 1 & -1 & -1 & 44.68 & 43.80 & 0.87 \\
6 & 1 & -1 & 1 & -1 & 28.71 & 27.84 & 0.87 \\
7 & 0 & 0 & 0 & 0 & 42.86 & 43.87 & -1.0 \\
8 & 1 & -1 & -1 & 1 & 48.08 & 47.20 & 0.87 \\
9 & 1 & -1 & -1 & -1 & 28.88 & 28.00 & 0.87 \\
10 & 1 & -1 & 1 & 1 & 41.53 & 40.65 & 0.87 \\
11 & 0 & 0 & 0 & 0 & 42.87 & 43.87 & -1.0 \\
12 & 1 & 1 & 1 & -1 & 55.40 & 54.52 & 0.87 \\
13 & 1 & 1 & 1 & 1 & 60,21 & 59.34 & 0.87 \\
\hline
\end{tabular}

\subsubsection{Pareto Chart}

The Pareto chart is a useful tool to identify the most important factors that influence the response. For the feed phase (Figure 6), the most influential factor was the interaction between the Aliquat-336 concentration and the temperature, followed by the interaction between the $\mathrm{Cr}(\mathrm{VI})$ concentration, the Aliquat-336 concentration, and the temperature, and, finally, the $\mathrm{Cr}(\mathrm{VI})$ concentration. Anupam et al. [43] reported in their study that $100 \%$ of $\mathrm{Cr}(\mathrm{VI})$ can be achieved at $\mathrm{pH} 2$ and $2 \mathrm{~g} \cdot \mathrm{L}^{-1}$ of powdered activated carbon. Their analysis of the Pareto chart shows that quantity-activated carbon was the most influencing factor of the system. Similar outcomes were obtained by Ben Khalifa et al. [44] using biosorbents based on orange peels, which could be explained by the increase in the number of active sites on the surface. 


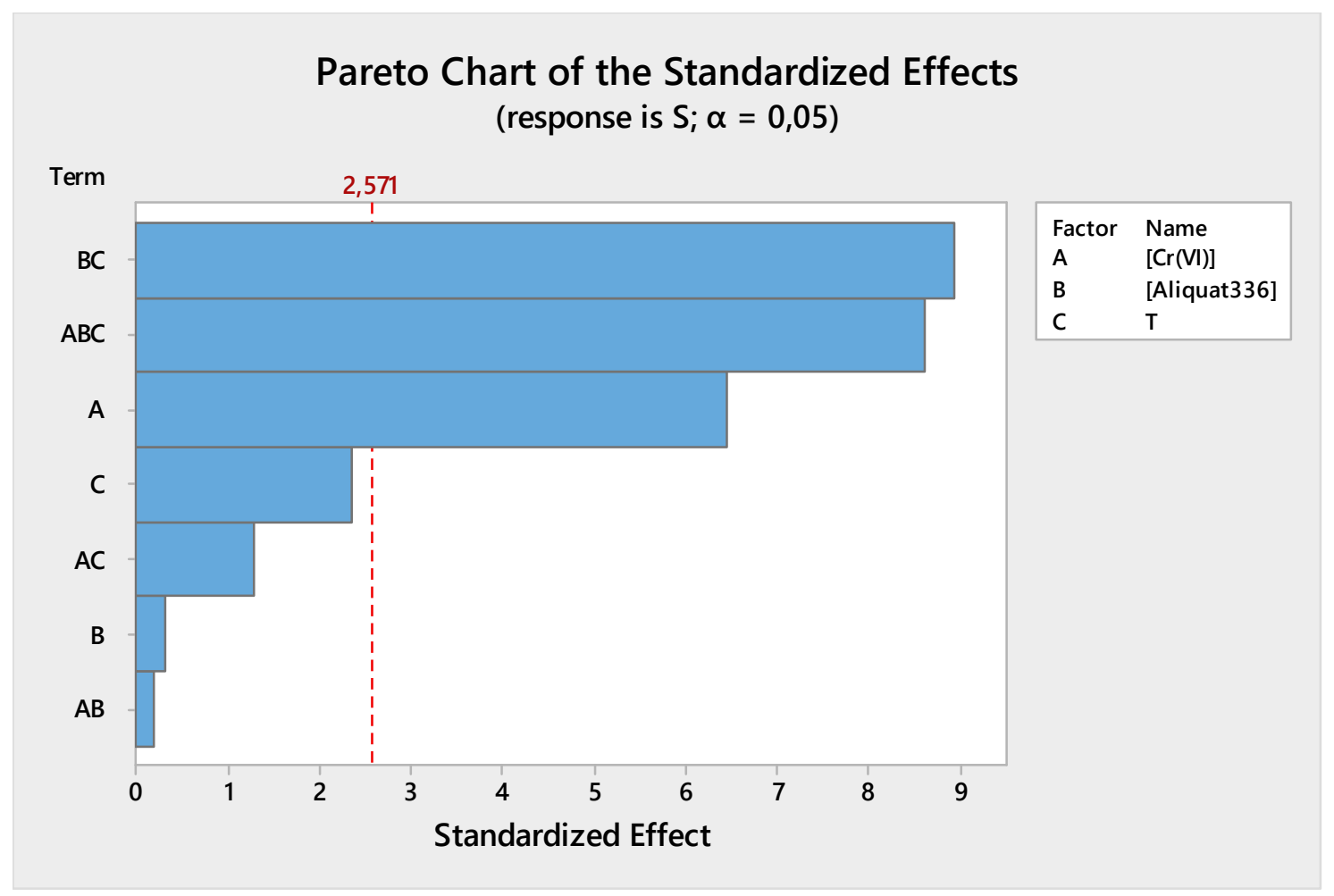

Figure 6. Feed phase Pareto chart of standardized effect.

From Figure 7, the most important factors influencing the back-extraction efficiency of $\mathrm{Cr}(\mathrm{VI})$ in the receiving phase were the $\mathrm{NaCl}$ concentration, the temperature, the $[\mathrm{NaCl}]$ * [Aliquat-336] interaction, and, finally, the $[\mathrm{NaCl}]{ }^{*} \mathrm{~T}$ interaction. However, [Aliquat-336], the [Aliquat-336] ${ }^{*} \mathrm{~T}$ interaction, and the $[\mathrm{NaCl}] *$ [Aliquat-336] * T interaction had a weak effect on the $\mathrm{Cr}(\mathrm{VI})$ back-extraction efficiency.

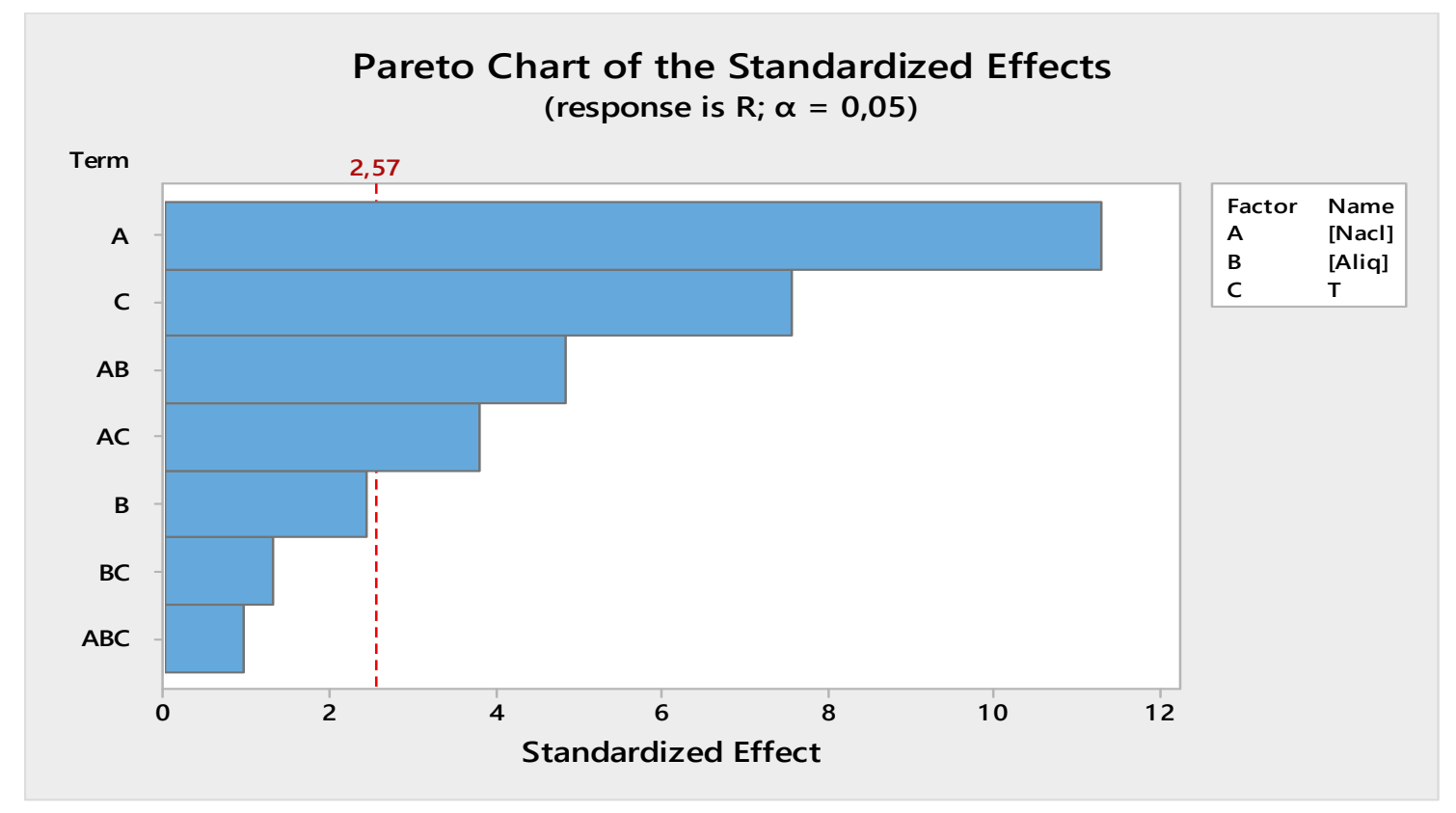

Figure 7. Receiving phase Pareto chart of standardized effect. 


\subsubsection{Main Effect Factors}

Figure 8 presents the main effects of the different factors studied in the source phase. It shows that the concentration of $\mathrm{Cr}(\mathrm{VI})$ and the concentration of Aliquat-336 had positive effects on the extraction efficiency of $\mathrm{Cr}(\mathrm{VI})$ in the source phase, while temperature had a negative effect on the extraction efficiency. In fact, by increasing the $\mathrm{Cr}(\mathrm{VI})$ content, the driving force increased with a consequent improvement of the extraction efficiency. Higher Aliquat-336 concentrations improved the $\mathrm{Cr}(\mathrm{VI})$ transport across the membrane, whilst higher source temperatures did not favor formation of the $\mathrm{Cr}(\mathrm{VI})$-Aliquat-336 complex, although diffusion of $\mathrm{Cr}(\mathrm{VI})$ ions to the membrane surface increased. Higher temperatures also led to a decrease of the viscosity of Aliquat-336, which can favor the release of Aliquat-336, with a consequent loss of efficiency.

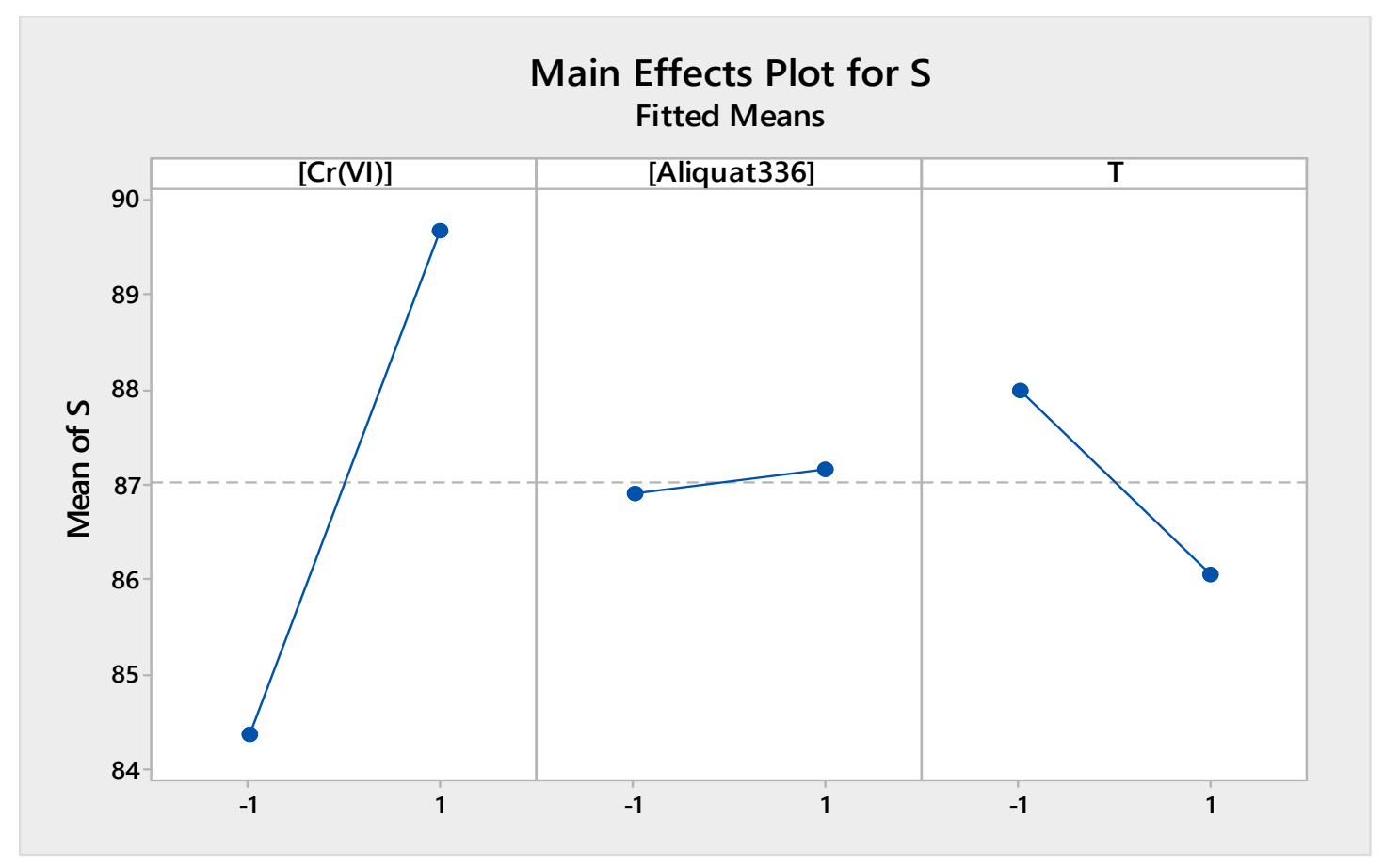

Figure 8. Factors of main effects plot for source phase.

Figure 9 shows the individual effects of the different factors selected for the receiving phase. It can be seen that the investigated factors ([Aliquat-336], [ $\mathrm{NaCl}]$ and $\mathrm{T}$ ) all had a positive effect on the back-extraction performance of $\mathrm{Cr}(\mathrm{IV})$ in the receiving phase. 


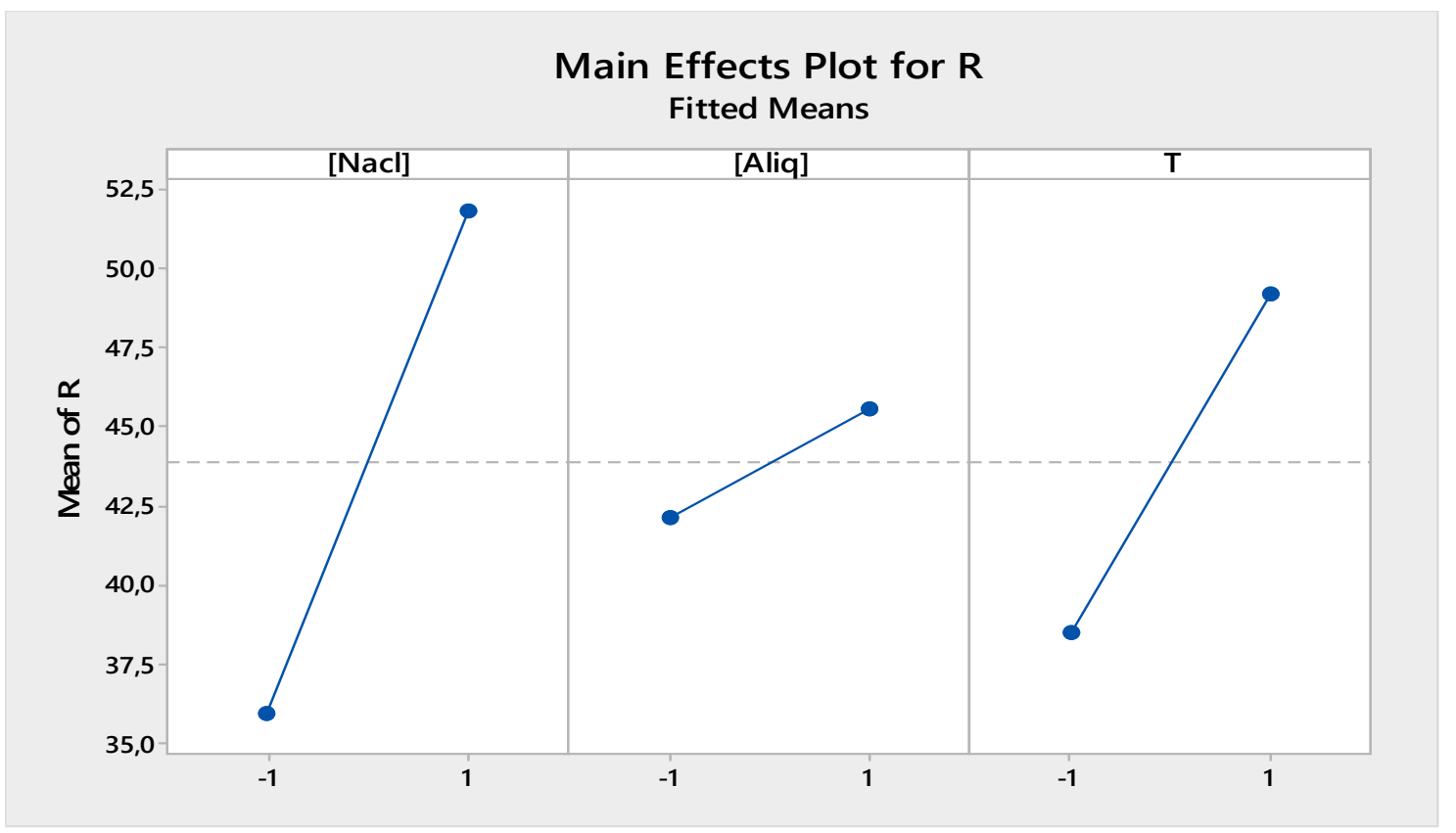

Figure 9. Factors of main effects plot for receiving phase.

\subsubsection{Interaction Effect Factors}

Figure 10 presents the interaction effect between the different factors studied. Their arrangements show that the interaction $\mathrm{T}$ * [Aliquat-336] was significant (strong interaction), while there was no interaction between $[\mathrm{Cr}(\mathrm{VI})]$ and temperature.

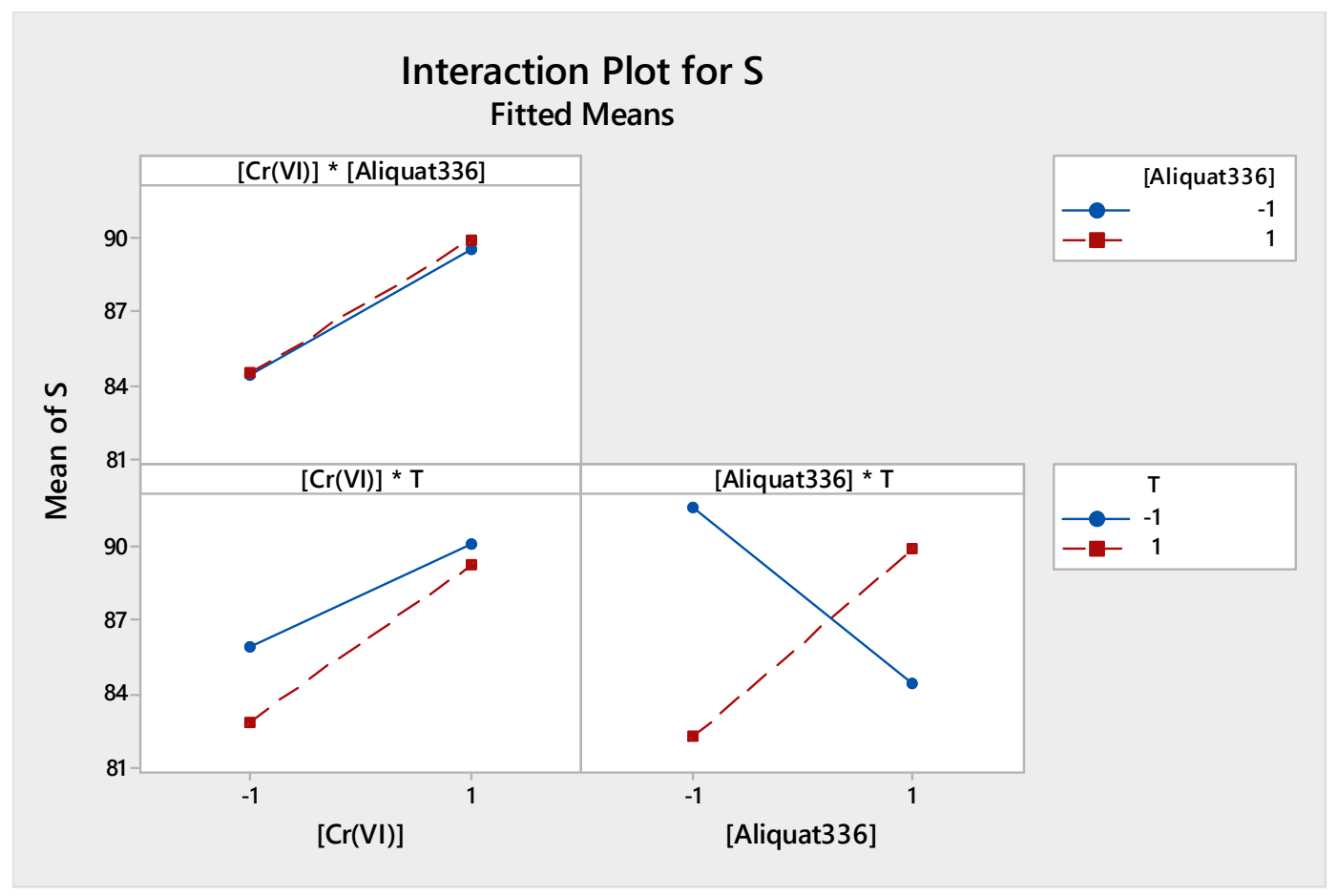

Figure 10. Factors of interactions effects plots for source phase.

Figure 11 shows the interaction effect between the different factors at two levels, -1 and 1 , in the receiving phase. Their arrangement shows a strong interaction between $[\mathrm{NaCl}]$ and [Aliquat-336] in 
the chosen field of study. However, the interactions $[\mathrm{T}]{ }^{*}\left[\right.$ Aliquat-336] and $[\mathrm{T}]{ }^{*}[\mathrm{NaCl}]$ were low and not significant.

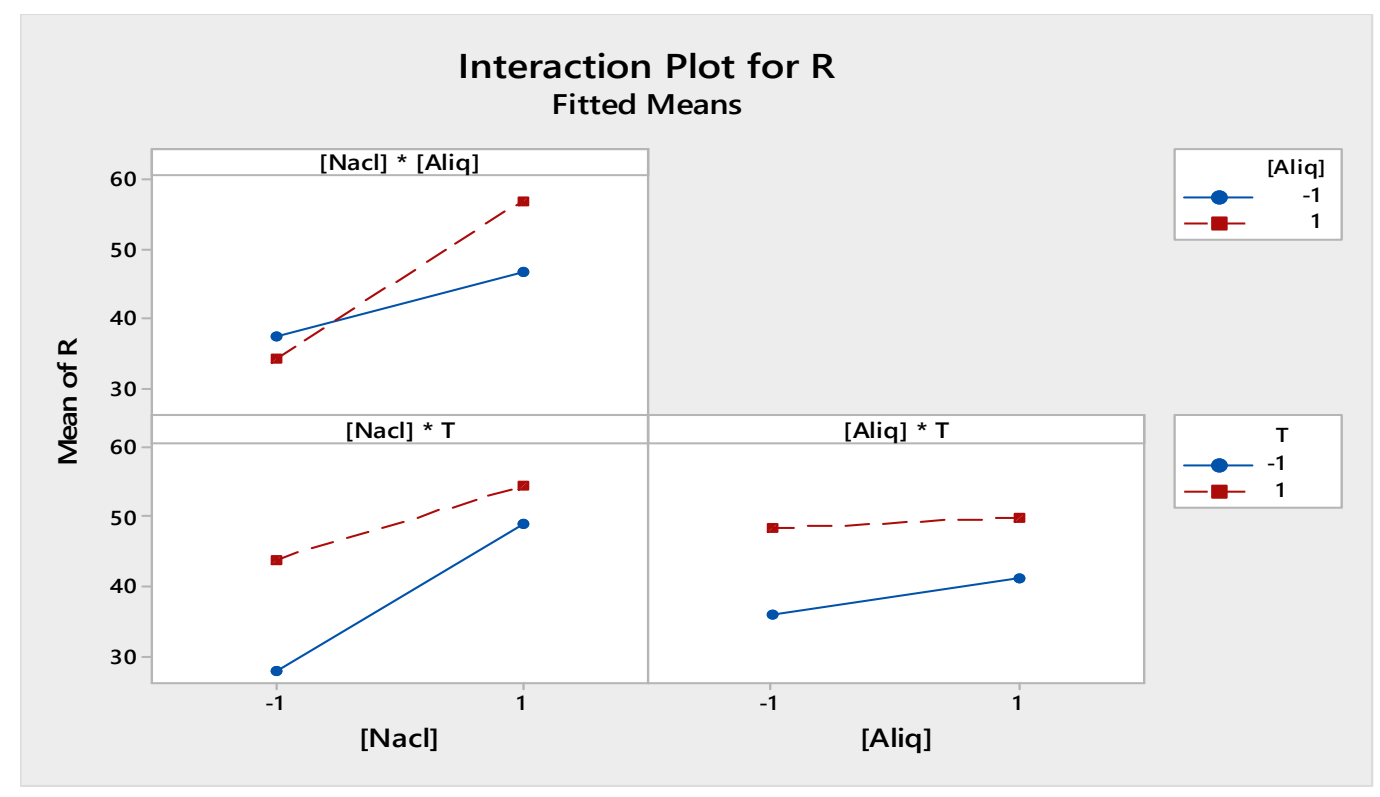

Figure 11. Factors of interactions effects plots for receiving phase.

3.2.4. Mathematical Model and Analysis of Variance

Source Phase

An analysis of variance (ANOVA) was conducted to examine the reliability of the model. ANOVA shows whether the model-related variations are significant compared to the variations in experimental results. According to the MINITAB software, the following regression equation was obtained:

$$
\begin{aligned}
\mathrm{S}= & 87.033+2.645[\mathrm{Cr}(\mathrm{VI})]+0.129\left[\text { Aliquat-336] }-0.967 \mathrm{~T}+0.077[\mathrm{Cr}(\mathrm{VI})]^{*}[\text { Aliquat-336] }\right. \\
& +0.530[\mathrm{Cr}(\mathrm{VI})]^{*} \mathrm{~T}+3.667\left[\text { Aliquat-336] }{ }^{*} \mathrm{~T}-3.530[\mathrm{Cr}(\mathrm{VI})]^{*}\left[\text { Aliquat-336] }{ }^{*} \mathrm{~T} .\right.\right.
\end{aligned}
$$

The individual effects, interaction effects, and model coefficients are presented in Table 6 . The main effects and interaction effects of each factor having a significance probability ( $P$-value) $\leq 0.05$ and a high Fisher's exact test (F-Value) means that this factor is significant.

Table 6. Factor effects and their coefficients.

\begin{tabular}{clc}
\hline Term & Effect & Coefficient \\
\hline Constant & & 87.033 \\
{$[\mathrm{Cr}(\mathrm{VI})]$} & 5.289 & 2.645 \\
{$[$ Aliquat-336] } & 0.257 & 0.129 \\
$\mathrm{~T}$ & -1.935 & -0.967 \\
{$[\mathrm{Cr}(\mathrm{VI})]^{*}[$ Aliquat-336] } & 0.155 & 0.077 \\
{$[\mathrm{Cr}(\mathrm{VI})]^{*} \mathrm{~T}$} & 1.059 & 0.530 \\
{$\left[\right.$ Aliquat-336] ${ }^{*} \mathrm{~T}$} & 7.333 & 3.667 \\
{$[\mathrm{Cr}(\mathrm{VI})]^{*}\left[\right.$ Aliquat-336] ${ }^{*} \mathrm{~T}$} & -7.060 & -3.530 \\
\hline
\end{tabular}

Table 7 summarizes the variance analysis. It reports both the significance probability and the Fisher's exact test. The results confirm that the factors [Aliquat-336], T, and interactions $\mathrm{T}^{*}$ [Cr (VI)] and $[\mathrm{Cr}(\mathrm{VI})]^{*}$ [Aliquat-336] had insignificant effects on the response, which was the extraction yield of $\mathrm{Cr}(\mathrm{VI})$ in the source phase. On the other hand, [Cr (VI)] and interactions [Aliquat-336] * $\mathrm{T}$ and [Cr(VI)] * [Aliquat-336] ${ }^{*}$ T had significant effects. 
Table 7. Analysis of variance.

\begin{tabular}{|c|c|c|c|c|c|}
\hline Source & DF $^{1}$ & Adj SS ${ }^{2}$ & Adj MS ${ }^{3}$ & F-Value & $P$-Value \\
\hline Regression & 7 & 273.116 & 39.017 & 29.14 & 0.001 \\
\hline$[\mathrm{Cr}(\mathrm{VI})]$ & 1 & 55.956 & 55.956 & 41.80 & 0.001 \\
\hline [Aliquat-336] & 1 & 0.132 & 0.132 & 0.10 & 0.766 \\
\hline $\mathrm{T}$ & 1 & 7.487 & 7.487 & 5.59 & 0.064 \\
\hline$[\mathrm{Cr}(\mathrm{VI})]^{*}[$ Aliquat-336] & 1 & 0.048 & 0.048 & 0.04 & 0.858 \\
\hline$[\mathrm{Cr}(\mathrm{VI})]^{*} \mathrm{~T}$ & 1 & 2.243 & 2.243 & 1.68 & 0.252 \\
\hline [Aliquat-336] ${ }^{*} \mathrm{~T}$ & 1 & 107.552 & 107.552 & 80.34 & 0.000 \\
\hline $\begin{array}{c}{[\mathrm{Cr}(\mathrm{VI})]^{*}[\text { Aliquat }-336] \text { * }} \\
\mathrm{T}\end{array}$ & 1 & 99.698 & 99.698 & 74.47 & 0.000 \\
\hline
\end{tabular}

After analysis of variance and by eliminating nonsignificant factors, the mathematical model obtained at the beginning becomes:

$$
\mathrm{S}=87.033+2.645[\mathrm{Cr}(\mathrm{VI})]+3.667\left[\text { Aliquat-336] }{ }^{*} \mathrm{~T}-3.530[\mathrm{Cr}(\mathrm{VI})]^{*}\left[\text { Aliquat-336] }{ }^{*} \mathrm{~T}\right. \text {. }\right.
$$

Figure 12 compares the experimental results of the $\mathrm{Cr}(\mathrm{VI})$ extraction performance with those predicted, showing a good agreement between experimental and predicted yields. The model shows a first-order linear regression with a high coefficient of determination, $R^{2}=97.77 \%\left(R^{2}\right.$ corr $\left.=94.26\right)$, indicating validation of the mathematical model.

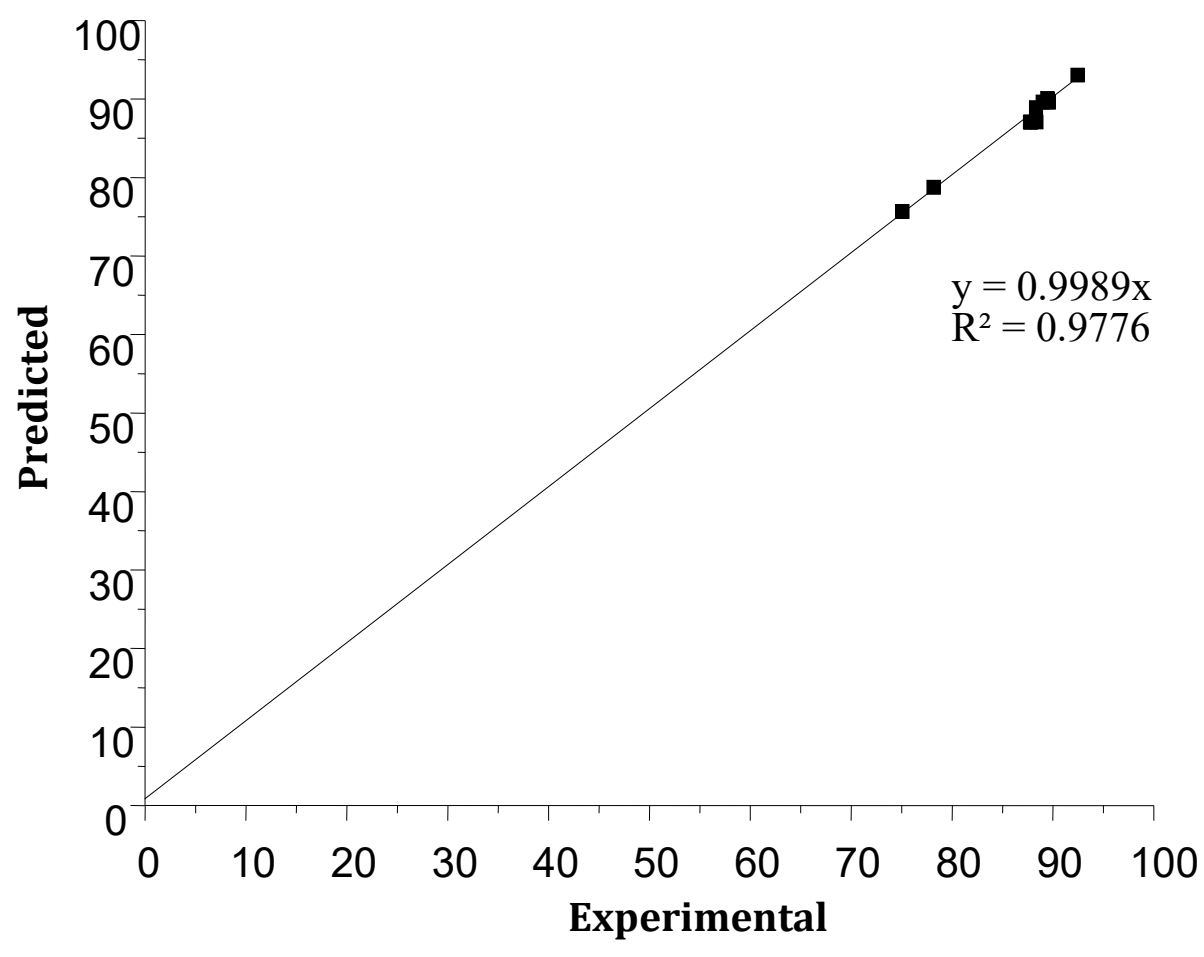

Figure 12. The predicted values of the response versus experimental values.

Receiving Phase

The MINITAB software allowed the processing of results by the following regression equation:

$$
\begin{aligned}
\mathrm{R}= & 43.872+7.945[\mathrm{NaCl}]+1.717[\text { Aliquat-336] }+5.329 \mathrm{~T}+3.397[\mathrm{NaCl}] *[\text { Aliquat-336] } \\
& -2.674[\mathrm{NaCl}] * \mathrm{~T}-0.921\left[\text { Aliquat-336] } * \mathrm{~T}+0.676[\mathrm{NaCl}] * \text { [Aliquat-336] }{ }^{*} \mathrm{~T} .\right.
\end{aligned}
$$


The individual, interaction. and model effects and coefficients are presented in Table 8.

Table 8. Predicted factor regression coefficients and their effect.

\begin{tabular}{|c|c|c|}
\hline Term & Effect & Coefficient \\
\hline Constant & & 43.872 \\
\hline$[\mathrm{NaCl}]$ & 15.891 & 7.945 \\
\hline [Aliquat-336] & 3.435 & 1.717 \\
\hline $\mathrm{T}$ & 10.658 & 5.329 \\
\hline$[\mathrm{NaCl}] *$ [Aliquat-336] & 6.794 & 3.397 \\
\hline$[\mathrm{NaCl}]^{*} \mathrm{~T}$ & -5.348 & -2.674 \\
\hline [Alqiaut336] ${ }^{*} \mathrm{~T}$ & -1.842 & -0.921 \\
\hline$[\mathrm{NaCl}] *[$ Aliquat -336$] * \mathrm{~T}$ & 1.351 & 0.676 \\
\hline
\end{tabular}

From the results of Table 9, it can be seen that a first-order linear regression was obtained. The factors $[\mathrm{NaCl}], \mathrm{T}$, and the two interactions $\mathrm{T} *[\mathrm{NaCl}]$ and $[\mathrm{NaCl}] *$ [Aliquat-336] had significant effects on the back-extraction performance of $\mathrm{Cr}(\mathrm{VI})$, whereas [Aliquat-336] and the interactions [Aliquat-336] ${ }^{*} \mathrm{~T}$ and $[\mathrm{Cr}(\mathrm{VI})] *[$ Aliquat-336] $* \mathrm{~T}$ had nonsignificant effects.

Table 9. Analysis of variance.

\begin{tabular}{|c|c|c|c|c|c|}
\hline Source & $\mathrm{DF}^{1}$ & Adj SS ${ }^{2}$ & Adj MS $^{3}$ & F-Value & $P$-Value \\
\hline Regression & 7 & 915.747 & 130.821 & 33.08 & 0.001 \\
\hline$[\mathrm{NaCl}]$ & 1 & 505.018 & 505.018 & 127.68 & 0.000 \\
\hline [Aliquat-336] & 1 & 23.597 & 23.597 & 5.97 & 0.058 \\
\hline $\mathrm{T}$ & 1 & 227.185 & 227.185 & 57.44 & 0.001 \\
\hline $\begin{array}{c}{[\mathrm{NaCl}]^{*}} \\
{[\text { Aliquat-336] }}\end{array}$ & 1 & 92.314 & 92.314 & 23.34 & 0.005 \\
\hline$[\mathrm{NaCl}] * \mathrm{~T}$ & 1 & 57.195 & 57.195 & 14.46 & 0.013 \\
\hline [Aliquat-336] $* \mathrm{~T}$ & 1 & 6.787 & 6.787 & 1.72 & 0.247 \\
\hline $\begin{array}{c}{[\mathrm{NaCl}]{ }^{*}} \\
\text { [Aliquat-336] }^{*} \mathrm{~T}\end{array}$ & 1 & 3.561 & 3.651 & 0.92 & 0.381 \\
\hline
\end{tabular}

After analysis of variance and by eliminating nonsignificant factors, the mathematical model obtained at the beginning becomes:

$$
\mathrm{R}=43.872+7.945[\mathrm{NaCl}]+5.329 \mathrm{~T}+3.397[\mathrm{NaCl}] * \text { [Aliquat-336] }-2.674[\mathrm{NaCl}] * \mathrm{~T} .
$$

Figure 13 shows the comparison between the experimental results of the back-extraction performance of $\mathrm{Cr}(\mathrm{VI})$ and those predicted. A good agreement between the experimental and predicted results was obtained (first-order linear regression with a determination coefficient of $R^{2}=97.89 \%$ $\left(R^{2}\right.$ corr $\left.\left.=94.93 \%\right)\right)$, then the reported model was validated. 


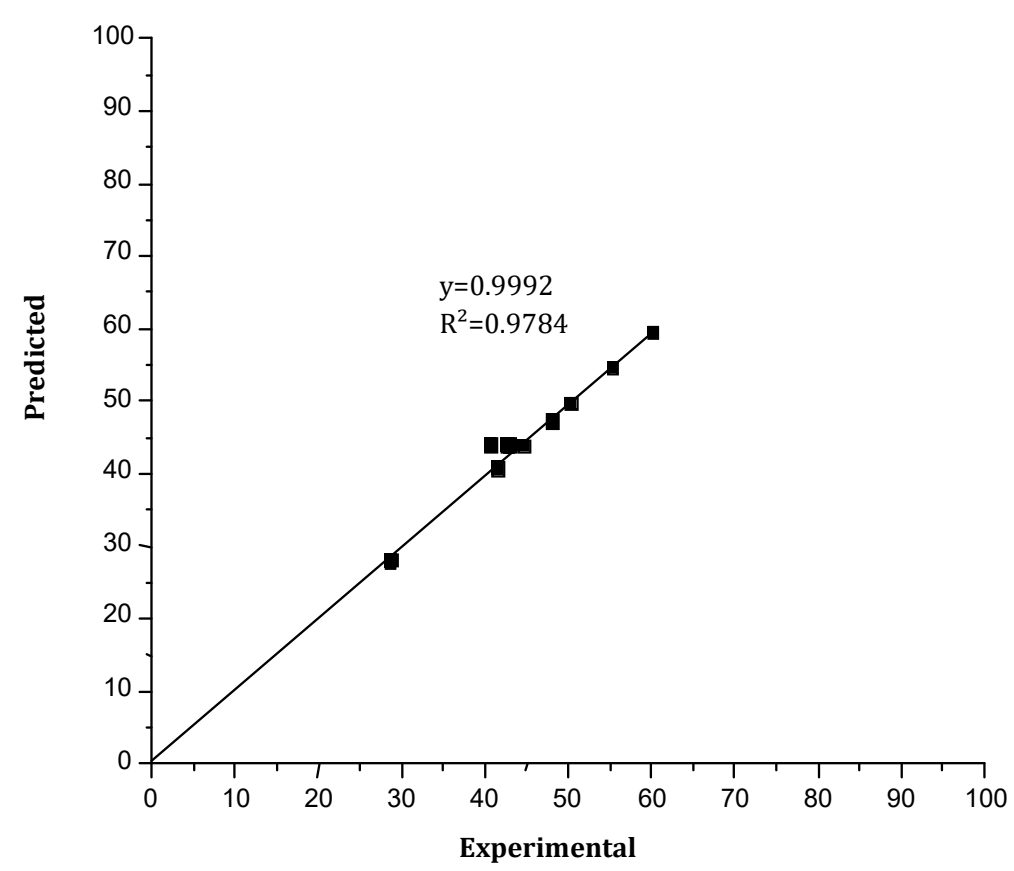

Figure 13. The back-extraction yield of $\mathrm{Cr}(\mathrm{VI})$ predicted versus the experimental yield.

\subsubsection{Response Contour}

The response of contour plots analyzes the interactions between two parameters to see the combined effect of each pair on the extraction/back-extraction efficiency of $\mathrm{Cr}(\mathrm{VI})$ while keeping the third parameter fixed.

Figure 14 shows the iso-response curves for the $\mathrm{Cr}(\mathrm{VI})$ extraction. The combined effect of two factors is studied on the response.

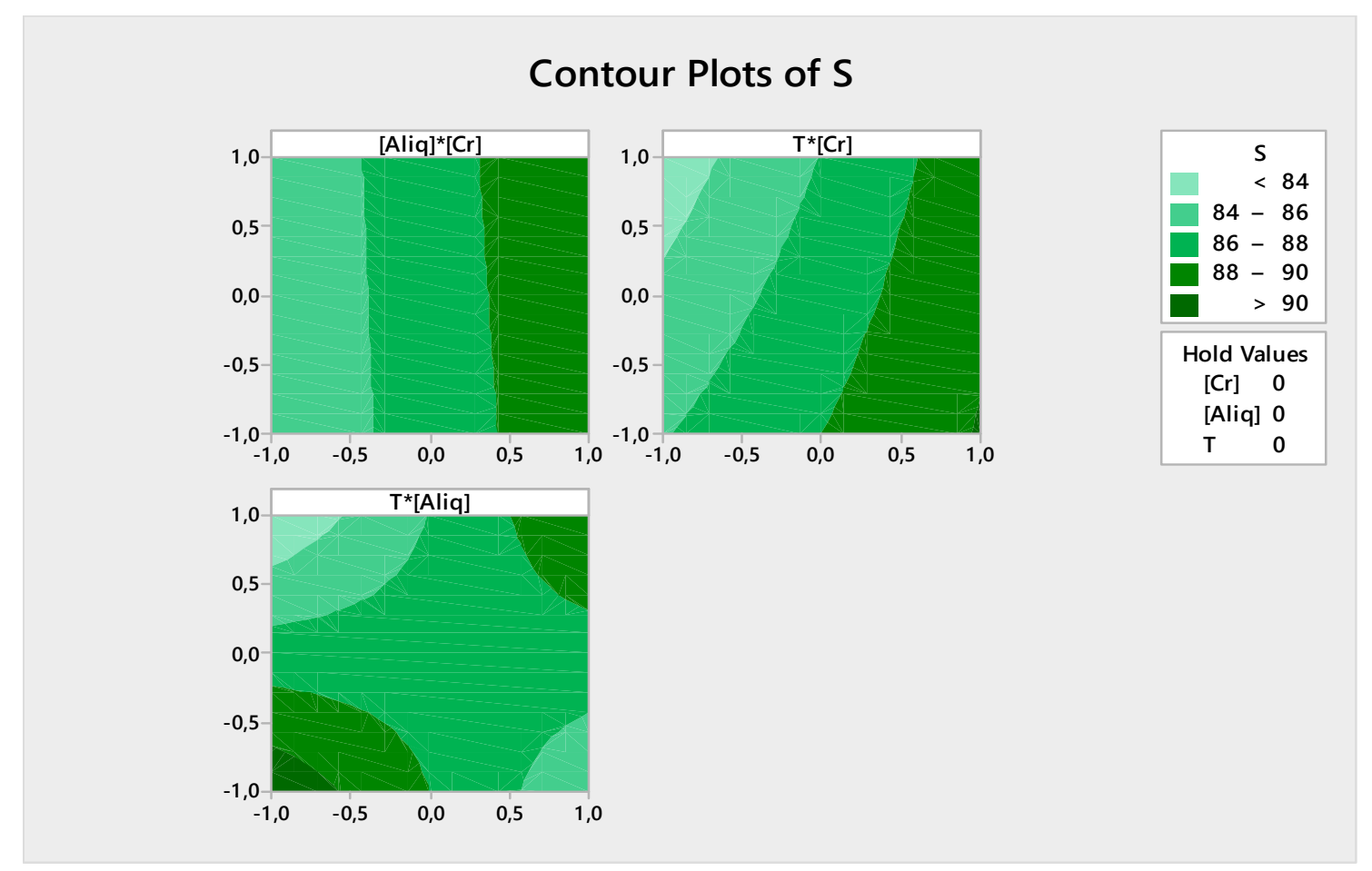

Figure 14. Contour plots of the extraction yield of $\mathrm{Cr}(\mathrm{VI})$. 
From Figure 14 it can be seen that:

- Extraction is better at a high $\mathrm{Cr}(\mathrm{VI})$ concentration at whatever Aliquat-336 concentration;

- Extraction is high $(>90 \%)$ at a high $\mathrm{Cr}(\mathrm{VI})$ concentration regardless of the temperature value; and

- The extraction efficiency is high $(>90 \%)$ when the Aliquat-336 concentration and temperature are at their maximum or minimum values.

Figure 15 shows the iso-response curves for the $\mathrm{Cr}(\mathrm{VI})$ back-extraction. The combined effect of two factors is studied on the response.

From Figure 15 it can be summarized that:

- The back-extraction efficiency of $\mathrm{Cr}(\mathrm{VI})$ is high ( $>55 \%$ ) when both $\mathrm{NaCl}$ and Aliquat-336 concentrations are high;

- The back-extraction efficiency of $\mathrm{Cr}(\mathrm{VI})$ is $>50 \%$ when the $\mathrm{NaCl}$ concentration and temperature reach their maximum values; and

- The back-extraction efficiency of $\mathrm{Cr}(\mathrm{VI})$ is $>45 \%$ when the Aliquat-336 concentration and temperature are high.

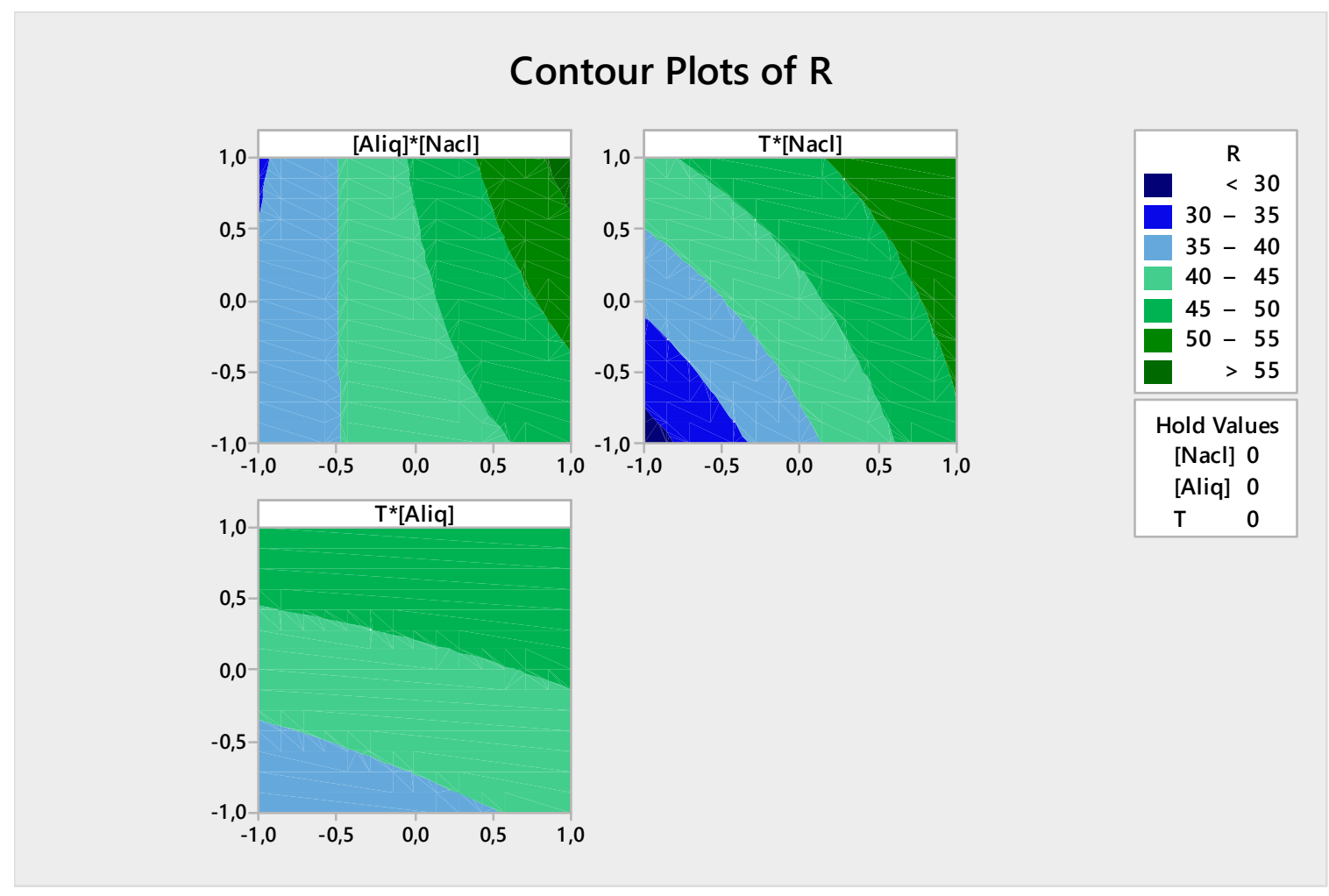

Figure 15. Contour plots of the back-extraction efficiency.

\subsubsection{Optimization}

One of the main objectives of this study was to find the optimal values of each parameter for which high extraction and back-extraction efficiencies of $\mathrm{Cr}(\mathrm{VI})$ are obtained.

From Figure 16, it can be seen that the extraction efficiency can reach a value of $93.03 \%$ when the values of the three parameters are as follows:

- $\quad \mathrm{Cr}(\mathrm{VI})$ concentration, $1.0 \mathrm{ppm}$;

- Temperature, $20^{\circ} \mathrm{C}$; and

- $\mathrm{PVC} /$ Aliquat-336 ratio, 1/0.5. 
Figure 17 shows the optimization of the different factors influencing the back-extraction efficiency of $\mathrm{Cr}(\mathrm{VI})$ in the receptor phase.

It can be deduced from these figures that the back-extraction efficiency of $\mathrm{Cr}(\mathrm{VI})$ in the receiving phase can reach a maximum value of $59.34 \%$ at the following parameter values:

- $\mathrm{NaCl}$ concentration, $2 \mathrm{M}$;

- Temperature, $50{ }^{\circ} \mathrm{C}$; and

- $\quad$ PVC/Aliquat-336 ratio, $1 / 1$.

Similar results were reported by Rajasimman et al. [45] in the extraction of $\mathrm{Cr}(\mathrm{VI})$ by emulsion liquid membranes by trioctyl amine using response surface methodology. A yield of $92.5 \%$ was achieved for the optimized conditions. In another comparative study between trioctyl amine and Aliquat-336 for $\mathrm{Cr}(\mathrm{VI})$ extraction by emulsion liquid membrane, Rajasimman et al. [46] reported a maximum extraction yield, under optimal conditions, of $89.2 \%$ and $96.15 \%$ for trioctyl amine TOA and Aliquat-336, respectively. The most influential parameters were agitation speed, the ratio of organic/aqueous phases, and concentration of the carriers. In the same system (ELM), Hashim et al. [47] demonstrated that the most influential parameters for $\mathrm{Cr}(\mathrm{VI})$ extraction by Cyanex 923 were concentration of the surfactant Span span and ratios of organic/internal or external phases. As reported by Saha et al. [48], more than $95 \%$ of $\mathrm{Cr}(\mathrm{VI})$ was extracted by Aliquat-336 in sunflower oil as solvent in bulk liquid membranes system. The transport of $\mathrm{Cr}(\mathrm{VI})$ through the bulk liquid membrane was influenced by strip phase concentration, strip phase $\mathrm{pH}$, and carrier concentration.

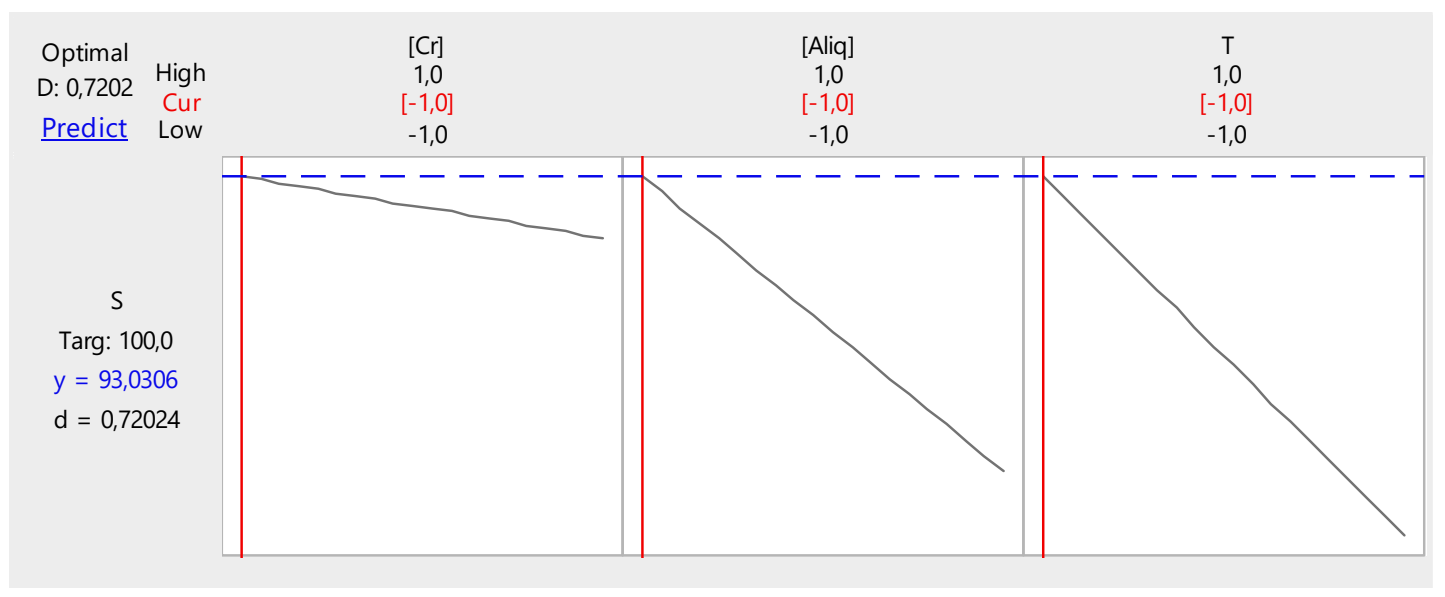

Figure 16. Factor optimization for $\mathrm{Cr}(\mathrm{VI})$ extraction.

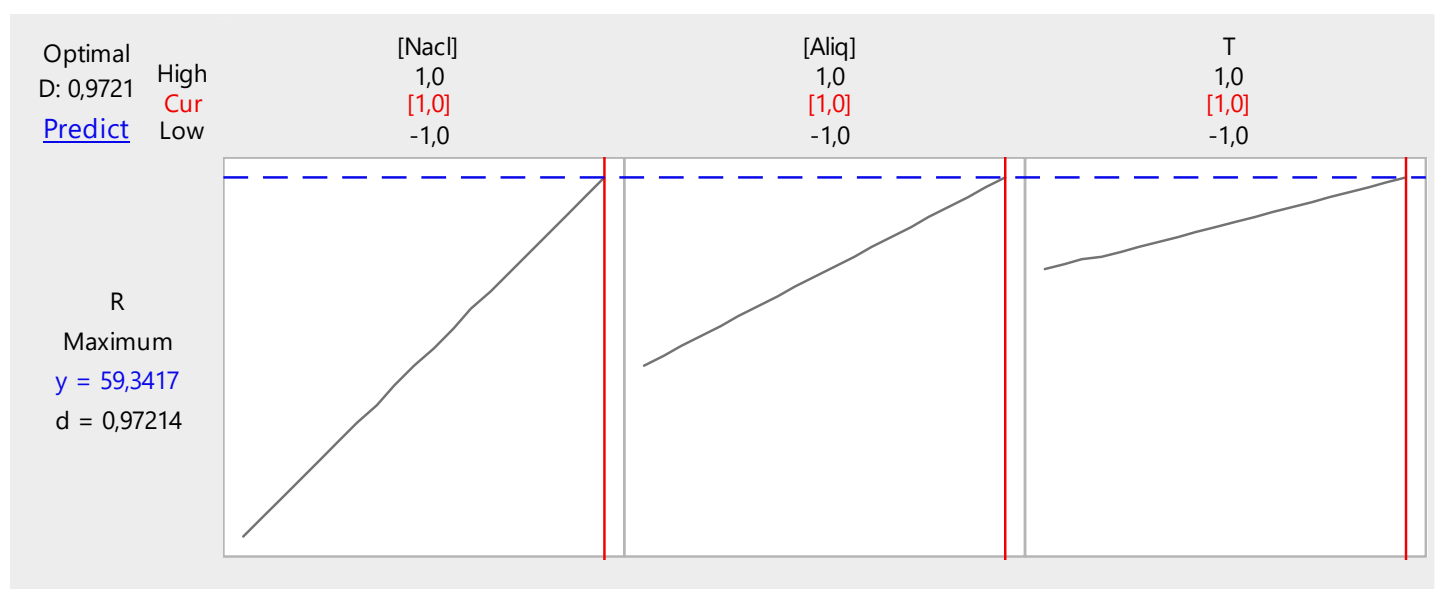

Figure 17. Optimization of back-extraction efficiency. 


\section{Conclusions}

A new application of PVC/Aliquat-336-based PIMs at different mass ratios (1/0.5, 1/0.75, and 1/1) using a multiframe flat sheet membrane module for $\mathrm{Cr}(\mathrm{VI})$ extraction has been successfully carried out. Nonrigid, dense, and transparent membranes, showing a plasticizing character due to the addition of the Aliquat-336 carrier, were produced. The presence of Aliquat-336 in the polymer matrix increases the hydrophilic character and the thickness of membranes.

To optimize the different parameters in the feed and receiving phases, a two-level, full factorial DOE was used. The developed model was validated with experimental data. From the results, the highest extraction efficiency of $93.03 \%$ can be reached by working at the following conditions in the feed phase: $10 \mathrm{ppm} \mathrm{Cr}(\mathrm{VI}), 20^{\circ} \mathrm{C}$, and PVC/Aliquat-336 ratio of $1 / 0.5$.

In the case of the receiving phase, the optimal value for the back-extraction yield of $59.34 \%$ can be obtained by working with: $\mathrm{NaCl}$ concentration of $2 \mathrm{M}, 50{ }^{\circ} \mathrm{C}$, and $\mathrm{PVC} /$ Aliquat-336 ratio of $1 / 1$. When working at the PVC/Aliquat-336 ratio of $1 / 0.5$, at which the highest extraction efficiency was obtained, the back-extraction efficiency decreased to $55.40 \%$.

The obtained results clearly indicate that the optimal yields of extraction and back-extraction cannot be reached with the same membrane. Moreover, even the highest back-extraction yield was always lower than the percentage of extraction ( $60 \%$ vs $93 \%$ ). A possible practical solution to increase the back-extraction could be to send, at the end of the extraction experiment, fresh receiving phases (at $50{ }^{\circ} \mathrm{C}$ and $\mathrm{NaCl} 2 \mathrm{M}$ ) at both sides of the membrane.

The multiframe module proposed in this work is an example of a compact design that could be adopted in scaling up the technique. This study focused on optimizing the parameters with synthetic solutions. Also, no effect of ionic forces was analyzed. In the future, the designed multiframe module could be a potential alternative to the classical double cell systems for continuous metal ion separation in real solutions.

Author Contributions: Experiments and calculations, writing the draft paper, H.S.; Membranes characterization, discussion of results, writing, S.B.; Membranes characterization, F.R.; Writing and reviewing the draft paper, A.F. and A.C.; Supervising, B.M. and E.D.

Funding: This research received no external funding.

Conflicts of Interest: The authors declare no conflict of interest.

\section{References}

1. Drioli, E.; Criscuoli, A.; Curcio, E. Membrane Contactors: Fundamentals, Applications and Potentialities, 1st ed.; Elsevier: Amsterdam, The Netherlands, 2006; pp. 1-516.

2. Bey, S.; Criscuoli, A.; Simone, S.; Figoli, A.; Benamor, M.; Drioli, E. Hydrophilic PEEK-WC hollow fibre membrane contactors for chromium (VI) removal. Desalination 2011, 283, 16-24. [CrossRef]

3. Bey, S.; Criscuoli, A.; Figoli, A.; Leopold, A.; Simone, S.; Benamor, M.; Drioli, E. Removal of As(V) by PVDF hollow fibers membrane contactors using Aliquat-336 as extractant. Desalination 2010, 264, 193-200. [CrossRef]

4. Aitali, S.; Kebiche-Senhadji, O.; Mansouri, L.; Benamor, M. Cationic dye (MB) removal using polymer inclusion membrane (PIMs). Procedia Eng. 2012, 33, 38-46.

5. Yoshida, W.; Baba, Y.; Kubota, F.; Kolev, S.D.; Goto, M. Selective transport of scandium(III) across polymer inclusion membranes with improved stability which contain an amic acid carrier. J. Membr. Sci. 2019, 572, 291-299. [CrossRef]

6. O'Rourke, M.; Cattrall, R.W.; Kolev, S.D.; Potter, I.D. The extraction and transport of organic molecules using polymer inclusion membrane. Solvent Extr. Res. Dev. 2009, 16, 1-12.

7. Sellami, F.; Kebiche-Senhadji, O.; Marais, S.; Couvrat, N.; Fatyeyeva, K. Polymer inclusion membranes based on CTA/PBAT blend containing Aliquat-336 as extractant for removal of $\mathrm{Cr}(\mathrm{VI})$ : Efficiency, stability and selectivity. J. React. Funct. Pol. 2019, 139, 120-132. [CrossRef]

8. Bukhari, F.; Suah, M.; Ahmad, M. Preparation and characterization of polymer inclusion membrane based optode for determination of $\mathrm{Al}^{3+}$ ion. Anal. Chim. Acta 2017, 951, 133-139. 
9. Specht, C.; Cattrall, R.W.; Spassov, T.G.; Spassova, M.I.; Kolev, S.D. Polymer inclusion membranes as substrates for controlled in-situ gold nanoparticle synthesis. J. React. Funct. Pol. 2018, 130, 81-89. [CrossRef]

10. Faye, M.C.; Denna, J.; Camitan, R.B.; Yabut, D.A.; Rivera, B.A.; Coo, L. Determination of Cu(II) in environmental water samples using polymer inclusion membrane-TAC optode in a continuous flow system. Sens. Act. B Chem. 2018, 260, 445-451.

11. Vera, R.; Fontàs, C.; Galceran, J.; Serra, O.; Anticó, E. Polymer inclusion membrane to access Zn speciation: Comparison with root uptake. Sci. Total Environ. 2018, 622-623, 316-324. [CrossRef]

12. Annane, K.; Sahmoune, A.; Montels, P.; Tingry, S. Polymer inclusion membrane extraction of cadmium(II) with Aliquat 336 in micro-channel cell. Chem. Eng. Res. Des. 2015, 94, 605-610. [CrossRef]

13. Bukhari, F.; Suah, M. Preparation and characterization of a novel Co(II) optode based on polymer inclusion membrane. Anal. Chem. Res. 2017, 12, 40-46.

14. Oberta, A.; Wasilewski, J.; Wódzki, R. Structure and transport properties of polymer inclusion membranes for $\mathrm{Pb}(\mathrm{II})$ separation. Desalination 2011, 271, 132-138. [CrossRef]

15. Vera, R.; Insa, S.; Fontàs, C. Enriqueta Anticó. A new extraction phase based on a polymer inclusion membrane for the detection of chlorpyrifos, diazinon and cyprodinil in natural water samples. Talanta 2018, 185, 291-298. [CrossRef] [PubMed]

16. Elias, G.; Díez, S.; Fontàs, C. System for mercury preconcentration in natural waters based on a polymer inclusion membrane incorporating an ionic liquid. J. Hazard. Mater. 2019, 371, 316-322. [CrossRef] [PubMed]

17. Turgut, H.I.; Eyupoglu, V.; Kumbasar, R.A.; Sisman, I. Alkyl chain length dependent Cr(VI) transport by polymer inclusion membrane using room temperature ionic liquids as carrier and PVDF-co-HFP as polymer matrix. Sep. Purif. Technol. 2017, 175, 406-417. [CrossRef]

18. Almeida, M.I.G.S.; Cattrall, R.W.; Kolev, S.D. Polymer inclusion membranes (PIMs) in chemical analysis. Anal. Chim. Acta 2017, 987, 1-14. [CrossRef] [PubMed]

19. Cai, C.; Yang, F.; Zhao, Z.; Liao, Q.; Bai, R.; Guo, W.; Chen, P.; Zhang, Y.; Zhang, H. Promising transport and high-selective separation of $\mathrm{Li}(\mathrm{I})$ from $\mathrm{Na}(\mathrm{I})$ and $\mathrm{K}(\mathrm{I})$ by a functional polymer inclusion membrane (PIM) system. J. Membr. Sci. 2019, 579, 1-10. [CrossRef]

20. Almeida, M.I.G.S.; Cattrall, R.W.; Kolev, S.D. Polymer inclusion membrane: concept and application. Procedia Eng. 2012, 44, 681-682. [CrossRef]

21. Almeida, M.I.G.S.; Cattrall, R.W.; Kolev, S.D. Recent trends in extraction and transport of metal ions using polymer inclusion membranes (PIMs). J. Membr. Sci. 2012, 415-416, 9-23. [CrossRef]

22. Ling, Y.Y.; Suah, F.B.M. Extraction of malachite green from wastewater by using polymer inclusion membrane. J. Environ. Chem. Eng. 2017, 5, 785-794. [CrossRef]

23. Meng, X.; Wang, C.; Ren, T.; Wang, L.; Wang, X. Electrodriven transport of chromium (VI) using 1-octanol/PVC in polymer inclusion membrane under low voltage. Chem. Eng. 2018, 346, 506-514. [CrossRef]

24. Yaftian, M.R.; Almeida, M.I.G.S.; Cattrall, R.W.; Kolev, S.D. Selective Extraction of Vanadium(V) from Sulfate Solutions into a Polymer Inclusion Membrane Composed of Poly(vinylidenefluoride-cohexafluoropropylene) and Cyphos IL 101. J. Membr. Sci. 2018, 545, 57-65. [CrossRef]

25. Malankowska, M.; Juliana, I.; Pellejero, I.; Rho, H.S.; Schlautmann, S.; Tiggelaar, R.M.; Pina, M.P.; Gardeniers, H.J.G.E.; Mallada, R. Understanding blood oxygenation in a microfluidic meander double side membrane contactor. Sens. Act. B Chem. 2019, 288, 414-424. [CrossRef]

26. Nghiem, L.D.; Mornane, P.; Potter, I.D.; Perera, J.M.; Cattrall, R.W.; Kolev, S.D. Extraction and transport of metal ions and small organic compounds using polymer inclusion membranes (PIMs). J. Membr. Sci. 2006, 281, 7-41. [CrossRef]

27. Bonggotgetsakul, Y.Y.N.; Cattrall, R.W.; Kolev, S.D. The Effect of Surface Confined Gold Nanoparticles in Blocking the Extraction of Nitrate by PVC-Based Polymer Inclusion Membranes Containing Aliquat 336 as the Carrier. Membranes 2018, 8, 6. [CrossRef] [PubMed]

28. Benavente, J.; Romero, V.; Vázquez, M.I.; Anticó, E.; Fontàs, C. Electrochemical Characterization of a Polymer Inclusion Membrane Made of Cellulose Triacetate and Aliquat 336 and Its Application to Sulfonamides Separation. Separations 2018, 5, 5. [CrossRef]

29. Vera, R.; Anticó, E.; Fontàs, C. The Use of a Polymer Inclusion Membrane for Arsenate Determination in Groundwater. Water 2018, 10, 1093. [CrossRef] 
30. Witt, K.; Radzyminska-Lenarcik, E.; Kosciuszko, A.; Gierszewska, M.; Ziuziakowski, K. The Influence of the Morphology and Mechanical Properties of Polymer Inclusion Membranes (PIMs) on Zinc Ion Separation from Aqueous Solutions. Polymers 2018, 10, 134. [CrossRef]

31. Zhang, N.; Liu, Y.; Liu, R.; She, Z.; Tan, M.; Mao, D.; Fu, R.; Zhang, Y. Polymer inclusion membrane (PIM) containing ionic liquid as a proton blocker to improve waste acid recovery efficiency in electrodialysis process. J. Membr. Sci. 2019, 581, 18-27. [CrossRef]

32. Wionczyk, B.; Apostoluk, W.; Prochaska, K.; Kozlowski, C.A. Properties of 4-(10-n-tridecyl)pyridine N-oxide in the extraction and polymer inclusion membrane transport of $\mathrm{Cr}(\mathrm{VI})$. Anal. Chim. Acta 2001, 428, 89-101. [CrossRef]

33. Scindia, Y.M.; Pandey, A.K.; Reddy, A.V.R. Coupled-diffusion transport of Cr(VI) across anion-exchange membranes prepared by physical and chemical immobilization methods. J. Membr. Sci. 2005, 249, 143-152. [CrossRef]

34. Cezary, A.; Kozlowski, C.A.; Walkowiak, W. Applicability of liquid membranes in chromium(VI) transport with amines as ion carriers. J. Membr. Sci. 2005, 266, 143-150.

35. Kebiche-Senhadji, O.; Mansouri, L.; Tingry, S.; Seta, P.; Benamor, M. Facilitated Cd(II) transport across CTA polymer inclusion membrane using anion (Aliquat 336) and cation (D2EHPA) metal carriers. J. Membr. Sci. 2008, 310, 438-445. [CrossRef]

36. Paulo, F.; Santos, L. Design of experiments for microencapsulation applications: A review. J. Mater. Sci. Eng. C 2017, 77, 1327-1340. [CrossRef] [PubMed]

37. Jacyna, J.; Kordalewska, M.; Markuszewski, M.J. Design of Experiments in metabolomics-related studies: An overview. J. Pharm. Biom. Anal. 2019, 164, 598-606. [CrossRef]

38. Kim, J.H.; Lee, J.M. Efficient online model-based design of experiments via parameter subset selection for batch dynamical systems. J. Comp. Chem. Eng. 2019, 121, 646-653. [CrossRef]

39. Nasser, I.I.; Amor, F.I.E.H.; Donato, L.; Algieri, C.; Garofalo, A.; Drioli, E.; Ahmed, C. Removal and recovery of $\mathrm{Ag}(\mathrm{CN})^{-2}$ from synthetic electroplating baths by polymer inclusion membrane containing Aliquat 336 as a carrier. Chem. Eng. 2016, 295, 207-217. [CrossRef]

40. Gherasim, C.-V.; Bourceanu, G.; Olariu, R.-I.; Arsene, C. A novel polymer inclusion membrane applied in chromium (VI) separation from aqueous solutions. J. Hazard. Mater. 2011, 197, 244-253. [CrossRef]

41. Ranjbar, S.; Tanhaei, B.; Ayati, A.; Sillapää, M. Novel Aliquat-336 impregnated chitosan beads for adsoptive removal of of anionic azo dyes. Int. J. Biol. Macrom. 2019, 125, 989-998. [CrossRef]

42. Vázquez, M.I.; Romero, V.; Fontàs, C.; Anticó, E.; Benavente, J. Polymer inclusion membranes (PIMs) with the ionic liquid (IL) Aliquat 336 as extractant: Effect of base polymer and IL concentration on their physical-chemical and elastic characteristics. J. Membr. Sci. 2014, 455, 312-319. [CrossRef]

43. Anupam, K.; Dutta, S.; Bhattacharjee, C.; Datta, S. Adsorptive removal of chromium (VI) from aqueous solution over powdered activated carbon: Optimisation through response surface methodology. Chem. Eng. J. 2011, 173, 135-143. [CrossRef]

44. Ben Khalifa, E.; Rzig, B.; Chakroun, R.; Nouagui, H.; Hamrouni, B. Application of response surface methodology for chromium removal by adsorption on low-cost biosorbent. Chem. Intell. Lab. Syst. 2019, 189, 18-26. [CrossRef]

45. Rajasimman, M.; Karthic, P. Application of response surface methodology for the extraction of chromium (VI) by emulsion liquid membrane. J. Taiwan Inst. Chem. Eng. 2010, 41, 105-110. [CrossRef]

46. Rajasimman, M.; Sangeetha, R. Optimization of process parameters for the extraction of chromium (VI) by emulsion liquid membrane using response surface methodology. J. Hazard. Mater. 2009, 168, 291-297. [CrossRef] [PubMed]

47. Hashim, M.A.; Nosrati, S.; Jayakumar, N.S. Extraction performance of chromium (VI) with emulsion liquid membrane by Cyanex 923 as carrier using response surface methodology. Desalination 2011, 266, 286-290.

48. Mondal, S.K.; Saha, P. Separation of hexavalent chromium from industrial effluent through liquid membrane using environmentally benign solvent: A study of experimental optimization through response surface methodology. Chem. Eng. Res. Des. 2018, 132, 564-583. [CrossRef]

(C) 2019 by the authors. Licensee MDPI, Basel, Switzerland. This article is an open access article distributed under the terms and conditions of the Creative Commons Attribution (CC BY) license (http://creativecommons.org/licenses/by/4.0/). 